\title{
Polymeric Nanoparticles for Breast Cancer Therapy: A Comprehensive Review
}

\author{
Ikmeet Kaur Grewal ${ }^{1,2}$ (D) , Sukhbir Singh ${ }^{1, *}$ (D), Sandeep Arora ${ }^{1}$ (D), Neelam Sharma ${ }^{1}$ (D) \\ 1 Chitkara College of Pharmacy, Chitkara University, Punjab, India \\ 2 Department of Pharmacy, Government Medical College, Patiala, Punjab, India \\ * Correspondence: singh.sukhbir12@gmail.com;
}

Scopus Author ID 56402098100

Received: 5.11.2020; Revised: 3.12.2020; Accepted: 5.12.2020; Published: 9.12.2020

\begin{abstract}
Breast cancer is a leading death cause in women globally. Since therapeutic products do not yet approach the tumor tissue at adequate levels; therefore, nanoparticle-based chemotherapy has been explored nowadays. Implementing nanotechnology to the treatment of breast cancer renders chemotherapy very successful and efficacious but far less toxic. In this review article, literature about polymeric nanoparticles applications in breast cancer was retrieved from PubMed, ScienceDirect, and Google Scholar databases. This review paper briefly addresses molecular targets in breast cancer's pathophysiology, drawbacks of current therapies for breast cancer, and polymeric nanoparticles as an evolving breast cancer chemotherapy that includes benefits, critical characteristics, and passive and active tumor targeting via polymeric nanoparticles. An outline of progression in polymeric nanoparticles for breast cancer treatment reports in current publications; patents available and clinical trials conducted for breast cancer in the last few years have been reviewed briefly.
\end{abstract}

Keywords: breast cancer; chemotherapy; clinical trials; patents; polymeric nanoparticle; tumour targeting.

(c) 2020 by the authors. This article is an open-access article distributed under the terms and conditions of the Creative Commons Attribution (CC BY) license (https://creativecommons.org/licenses/by/4.0/).

\section{Introduction}

Breast cancer is the most frequent carcinoma in females and a common cause of cancerrelated mortality in women worldwide [1,2]. Chemotherapeutic agents, combined with radiation therapy and surgical intervention, constitute the first treatment option for breast cancer [3]. However, pharmacotherapy has been modified since medicinal products do not yet penetrate the tumor site at adequate levels, increasing systemic side effects, and reduced pharmacokinetics. The application of nanotechnology for breast cancer treatment makes chemotherapy more efficient and successful, and less harmful. Several types of cancers acquire multidrug resistance, which seems to be a critical reason for several chemotherapeutics categories' failure.

Consequently, over the past couple of years, different hybrid polymer nanoparticles have been designed to treat breast cancer. In recent years, nanoparticles have been designed for in-vivo cancer diagnostics, molecular biology screening of biological markers for tumors, and targeted medications delivery. Such nanotechnology-based strategies could be primarily used to treat various malignant conditions [4].

The literature was retrieved from databases like PubMed, Google Scholar, and ScienceDirect for this article's compilation. Patents regarding nanoparticles in the treatment of breast cancer have been collected from the WIPO. Clinical trials based related to breast cancer 
have also been summarized in this review. The key terms utilized were 'breast cancer', 'polymeric nanoparticles', and 'formulation for breast cancer' in different combinations. This review article briefly discusses molecular targets in breast cancer pathophysiology, limitations of current breast cancer treatments, and polymeric nanoparticles as a promising technology designed for breast tumor treatment, which includes advantages, essential characteristics, and active and passive tumor targeting polymeric nanoparticles. An overview of polymeric nanoparticles' advancements for breast cancer therapy reported in recent publications, patents published, and clinical trials conducted related to breast cancer therapy in the last few years has been summarized.

\section{Molecular Targets, Types, and Detection of Breast Cancer}

The main molecular targets identified to be involved in the pathophysiology of breast cancer include estrogen receptor alpha (ER $\alpha)$ and epidermal growth factor-2 (ERBB-2). ER $\alpha$ is a steroid hormone receptor expressed in about $70 \%$ of cases of invasive breast cancers. It is a transcription factor which on activation through estrogen, stimulates oncogenic development pathways within breast cancer cells [5-11]. ERBB-2 is over-expressed in around 20\% of breast cancers. Besides these, triple-negative breast cancer (TNBC) accounts for approximately $15 \%$ of all breast tumors. It has been characterized by a lack of activation of molecular targets such as estrogen and progesterone receptors or ERBB2 receptors. The different types of breast cancer and TNBC have been depicted in Figure 1 [12-19].

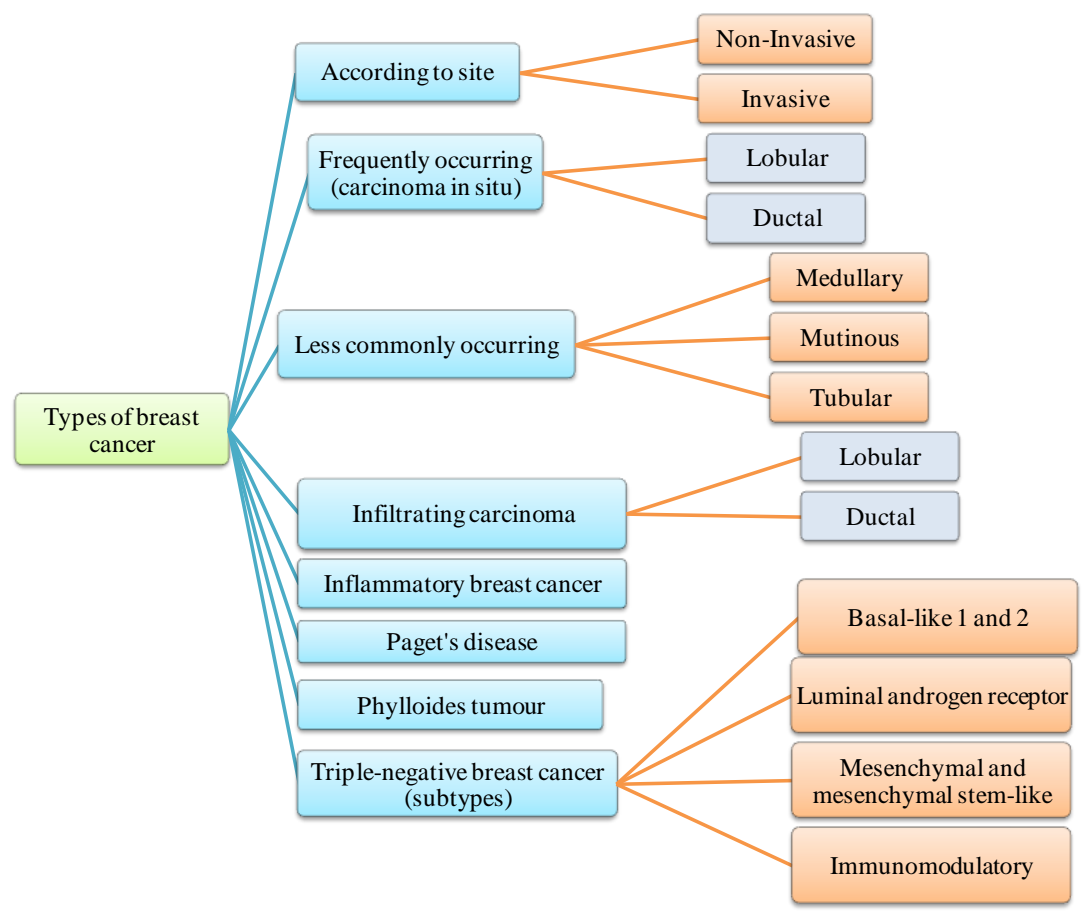

Figure 1. Types of breast cancer.

Basal-like-1 TNBC is characterized by a high response to DNA damage as well as Ki67 levels. The androgen receptor is abundantly expressed in the luminal androgen receptor, with an abundance 10-times stronger than the other subtypes. The mesenchymal stem-like TNBC is distinguished by elements that interact with G-protein receptors, calcium signaling, and EGFR. The immunomodulatory TNBC is attributed to the greater expression of STAT genes that control $\mathrm{T}$ and $\mathrm{B}$-cells and natural killer cells. The techniques for breast cancer detection have been depicted in Figure 2 [20-30]. 


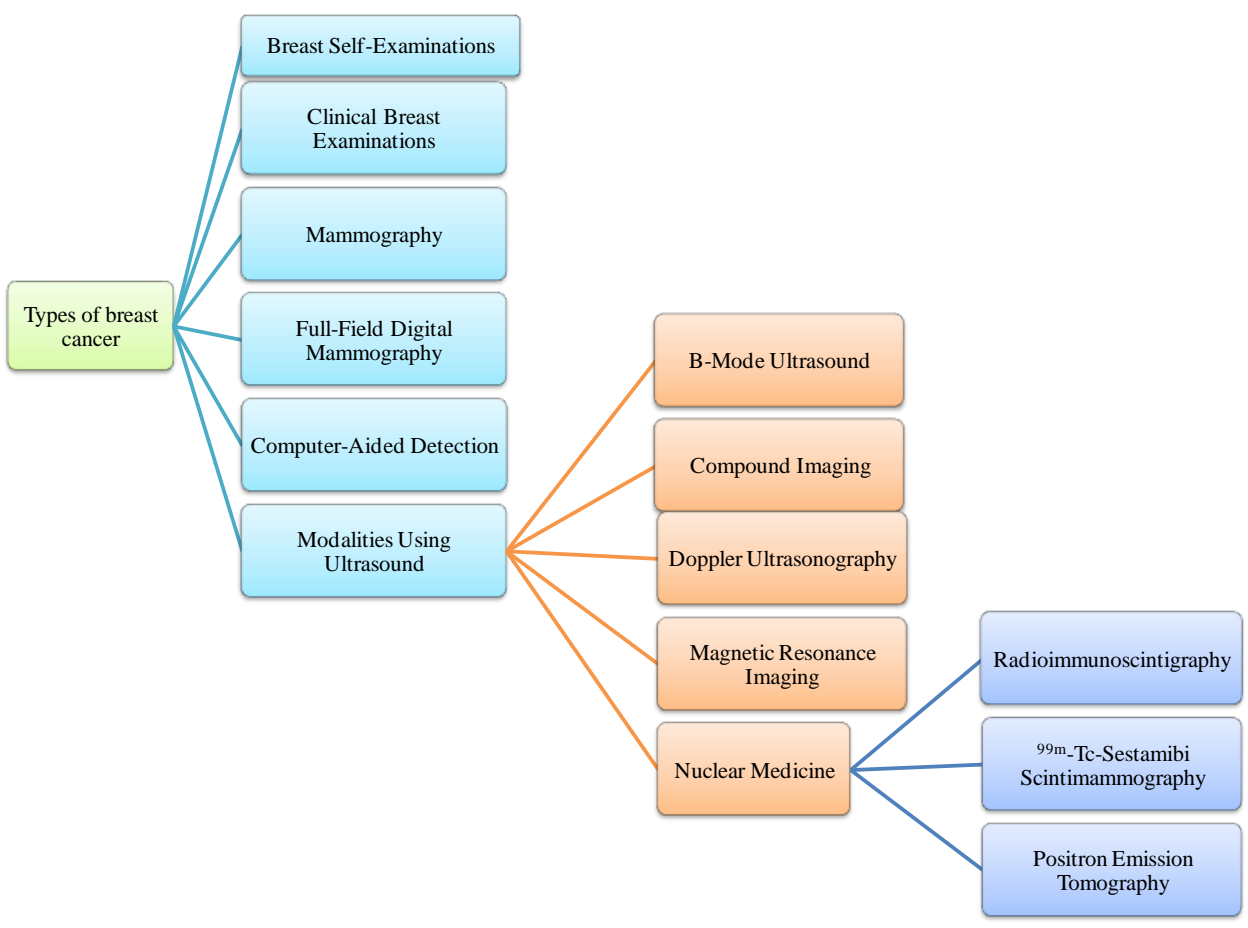

Figure 2. Technique for the detection of breast cancer.

\section{Limitations of Current Breast Cancer Treatments}

Existing treatment strategies have several shortcomings in the treatment of breast cancer, which includes lack of selective toxicity, which leads to diminished therapeutic efficacy and, as an outcome, the medical diagnosis being impaired; injury to healthy tissues and therefore, decreased doses of anticancer medicines are generally delivered to minimize toxicity to normal tissues; poor bio-distribution and drug penetration in solid tumors; heterogenic vessels in tumor sites increases extravasation of drugs. Current treatments tend greater drug deposition in normal viscera (10- to 20 -fold greater) than that in a comparably loaded tumor site, and several chemotherapeutic agents are unable to permeate from the vasculature more than 40-50 mm (equivalent to the combined diameter of three to five cells) which could result in multiple drug resistance (MDR) and ultimately therapeutic failure. Furthermore, the development of MDR in tumor cells on treatment with one anticancer molecule could generate resistance to an entire range of drugs owing to over-expression of drug efflux proteins [31-34].

\section{Polymeric Nanoparticle as an Emerging Technology for Breast Cancer Therapy}

\subsection{Advantages of polymeric nanoparticles.}

Nanotechnology offers a more targeted stratagem for resolving conventional chemotherapies' shortcomings and may have great advantages for people living with cancer. Polymeric nanoparticles include several benefits against free drugs, such as drug safety against initial deterioration, increased drug permeability into a targeted tissue, controlled delivery of drug and augmented intracellular permeation, drug avoidance from preterm physiological interference, and diminished toxicity $[35,36]$.

\subsection{Essential characteristics of polymeric biomaterials.}

Biocompatible polymers must be employed to manufacture polymeric nanoparticles to acquire quick and effective clinical translation. Furthermore, these nanocarriers should be 
surface functionalized to achieve extended biological circulation, least tendency to aggregation, and superior uptake efficiency in targeted tumor cells. The examples of polymers that could be utilized for the manufacturing of polymeric nanoparticles include poly-lactic-coglycolic acid (PLGA), poly-lactic acid (PLA), polyethylene glycol (PEG), chitosan, alginate, and pectin $[35,36]$.

\subsection{Active tumor targeting.}

Targeting agents that could be conjugated over the surface of nanocarriers includes proteins, i.e., antibodies, peptides, aptamers, nucleic acids, small organic molecules, vitamins, and carbohydrates. The particular marker should be over-expressed on cancerous cells in comparison to healthy tissues, and targeting nanocarriers should have great selectivity to molecules that are distinctively expressed over the tumor cell's surface. When specific entities are being used to transmit nanocarriers to solid tumors, it's indeed vitally important that agents links to receptors specifically expressed on the target cells [37-42].

\subsection{Passive targeting.}

Passive targeting of circulating nanoparticles into tumor cells could be achieved through enhanced permeation and retention effect (EPR), which has been schematically represented in Figure 3 [37-42].

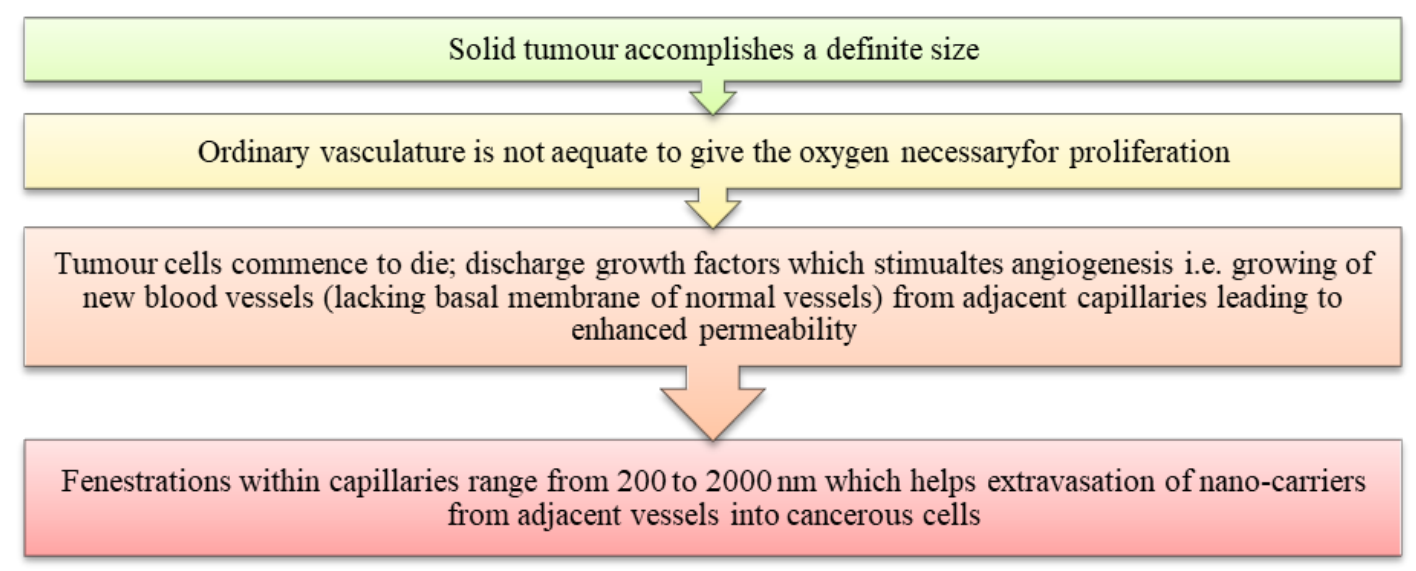

Figure 3. Passive tumor targeting via enhanced permeation and retention effect.

\section{Recent Advancements in Nanotechnology-Based Formulation for Breast Cancer Therapeutics}

Innovative nanotechnology approaches have become essential for dealing with challenging illness conditions. Consequently, the relevance of promising polymeric nanoparticles strategies like stealth, magnetic, conjugated, and hybrid nanoparticles for breast cancer therapy has become necessary currently. Table 1 summarizes the recent applications of polymeric nanoparticles for breast cancer chemotherapeutics. Table 2 recapitulates the current patents based on the relevance of nanoparticles in breast tumor management.

Table 1. Recent polymeric nanoparticles explored for breast cancer therapeutics.

\begin{tabular}{l|l|l|l|l|l} 
Drug & Polymer/lipid & $\begin{array}{l}\text { Preparation } \\
\text { technique }\end{array}$ & Outcomes & Refs. \\
\hline Doxorubicin & Poloxamer 407, holo-transferrin & $\begin{array}{l}\text { Modified thin-film } \\
\text { hydration }\end{array}$ & $\begin{array}{l}\text { Overcome drug-resistant } \\
\text { chemotherapy }\end{array}$ & {$[43]$}
\end{tabular}


https://doi.org/10.33263/BRIAC114.1115111171

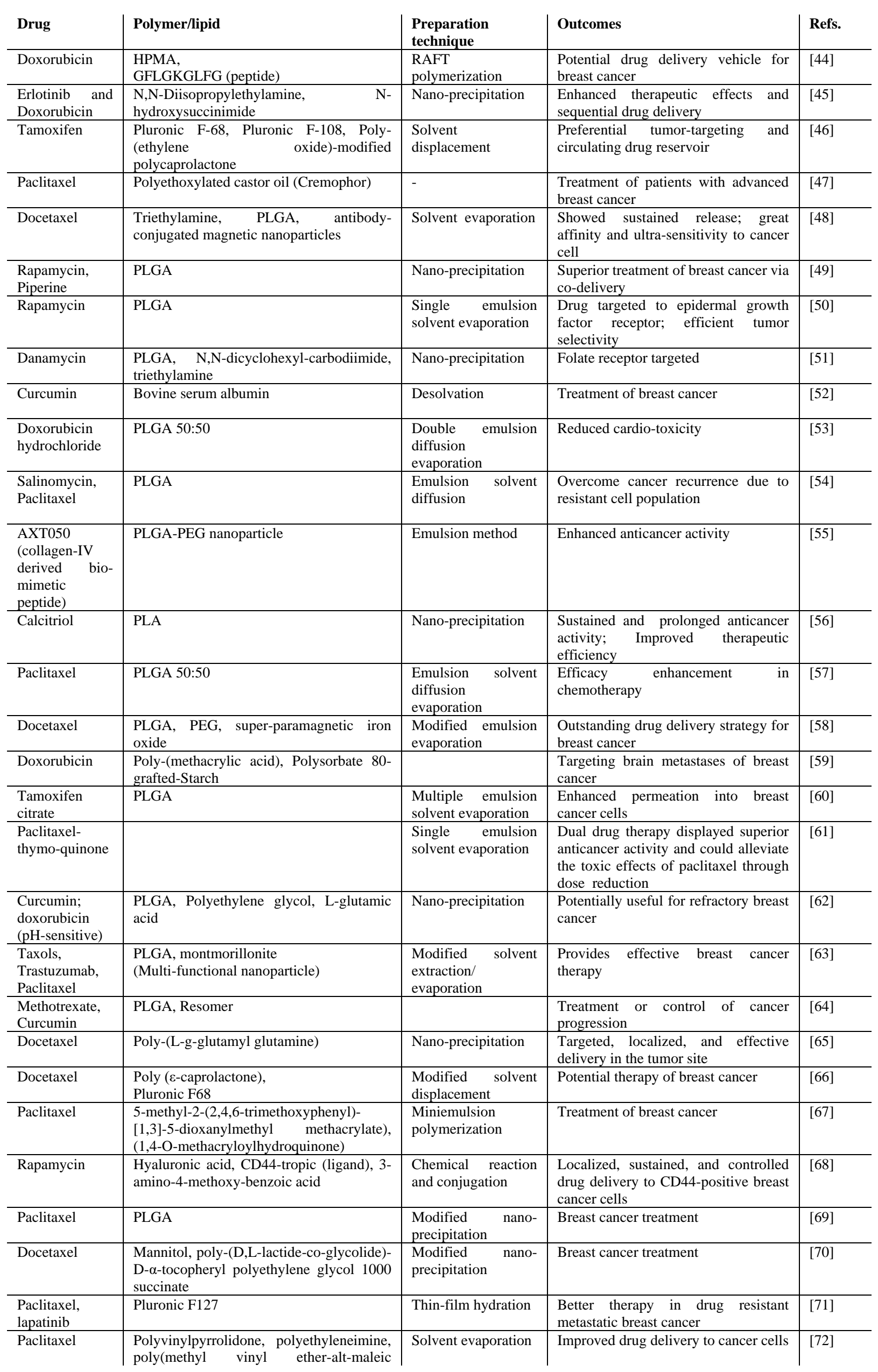


https://doi.org/10.33263/BRIAC114.1115111171

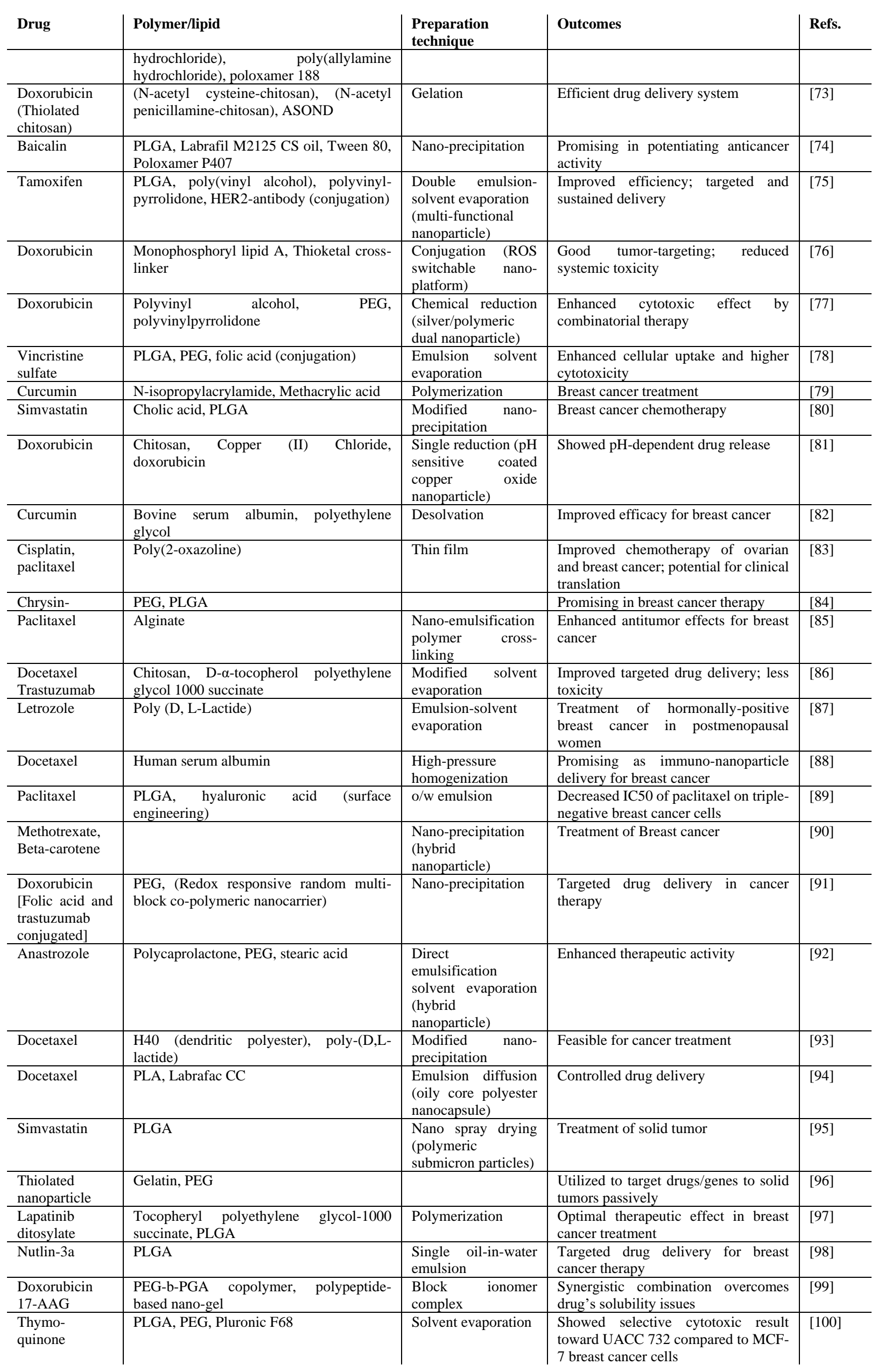




\begin{tabular}{|c|c|c|c|c|}
\hline Drug & Polymer/lipid & $\begin{array}{l}\text { Preparation } \\
\text { technique }\end{array}$ & Outcomes & Refs. \\
\hline $\begin{array}{l}\text { Doxorubicin, } \\
\text { GG918 } \\
\text { (Elacridar) }\end{array}$ & & Ultra-sonication & $\begin{array}{l}\text { Simultaneous delivery with the } \\
\text { superior treatment of multidrug- } \\
\text { resistant breast cancer }\end{array}$ & {$[101]$} \\
\hline Vinorelbine & PLGA, PEG, aptamer (bio-conjugate) & $\begin{array}{l}\text { Emulsion/solvent } \\
\text { evaporation }\end{array}$ & Targeted effect for breast cancer & {$[102]$} \\
\hline $\begin{array}{l}\text { Paclitaxel, } \\
\text { (stealth } \\
\text { nanoparticle) }\end{array}$ & $\begin{array}{l}\begin{array}{l}\text { Poly-(ethylene glycol)-block-poly( }(\varepsilon- \\
\text { caprolactone), } \\
\text { phosphatidylcholine, cholesterol }\end{array} \\
\end{array}$ & Thin film hydration & $\begin{array}{l}\text { Improved drug accumulation at the } \\
\text { target tumor site achieved via PEG } \\
\text { modification }\end{array}$ & [103] \\
\hline Docetaxel & PLGA (polymer hybrid nanoparticle) & Nano-precipitation & $\begin{array}{l}\text { Advanced therapeutics to combat } \\
\text { breast cancer }\end{array}$ & {$[104]$} \\
\hline Doxorubicin & $\begin{array}{l}\text { PLGA, lecithin, DSPE-PEG-2000 (Lipid- } \\
\text { polymer hybrid nanoparticle) }\end{array}$ & $\begin{array}{l}\text { Single-step modified } \\
\text { nano-precipitation }\end{array}$ & $\begin{array}{l}\text { Controlled drug (both hydrophilic/ } \\
\text { lipophilic form) delivery }\end{array}$ & {$[105]$} \\
\hline Docetaxel & Mono-methoxy-PEG-PLA & Thin-film hydration & $\begin{array}{l}\text { Showed better antitumor efficacy in } \\
\text { breast cancer therapy }\end{array}$ & {$[106]$} \\
\hline Curcumin- & PLGA & Solvent evaporation & $\begin{array}{l}\text { Improved bioavailability of curcumin } \\
\text { for the treatment of severe malignant } \\
\text { breast cancer }\end{array}$ & [107] \\
\hline Curcumin & Chitosan, folic acid & - & $\begin{array}{l}\text { Potential drug delivery for breast } \\
\text { cancer therapy }\end{array}$ & {$[108]$} \\
\hline Dasatinib & Poly(cyclohexene phthalate) & Nano-precipitation & $\begin{array}{l}\text { Controlled drug delivery for breast } \\
\text { cancer treatment }\end{array}$ & [109] \\
\hline
\end{tabular}

17-AAG: 17-allylaminodemethoxygeldanamycin; ASOND: antisense oligonucleotide; IC50: drug concentration which is required for $50 \%$ inhibition in-vitro; DSPE-PEG-2000: 1,2-distearoyl-sn-glycero-3phosphoethanolamine-N-[amino(polyethylene glycol)-2000]; HPMA: N-(2-Hydroxypropyl) methacrylamide); PEG: polyethylene glycol; PLGA: Poly-(D,L-lactide-co-glycolide); PLA: Poly-(D,L-lactic acid), RAFT: reversible addition-fragmentation chain-transfer; ROS: reactive oxygen species.

Table 2. Recent patents based on the relevance of nanoparticles in breast cancer therapy.

\begin{tabular}{|c|c|c|c|c|}
\hline Patent name & Patent number & Applicant & Year & Refs. \\
\hline $\begin{array}{l}\text { Liposomal curcumin for the } \\
\text { treatment of cancer }\end{array}$ & WO/2004/080396 & The University of Texas Md Anderson & 2004 & [110] \\
\hline $\begin{array}{l}\text { In vivo imaging and therapy with } \\
\text { magnetic nanoparticles conjugates }\end{array}$ & $\mathrm{WO} / 2007 / 021621$ & $\begin{array}{l}\text { Board of supervisors of Louisiana state } \\
\text { university and agricultural and } \\
\text { mechanical college }\end{array}$ & 2007 & [111] \\
\hline $\begin{array}{l}\text { In-vivo imaging and therapy with } \\
\text { magnetic nanoparticles conjugates }\end{array}$ & EP1912564 & Univ Lousiana state & 2008 & [112] \\
\hline $\begin{array}{l}\text { Breast cancer therapy based on } \\
\text { hormone receptors status with } \\
\text { nanoparticles comprising a taxane }\end{array}$ & $\begin{array}{l}\text { WO/2008/076373 } \\
\text { CA2672618 } \\
\text { EP2117520 } \\
\text { US20100048499 }\end{array}$ & Abraxis Bioscience, LLC & 2008 & $\begin{array}{l}{[113]} \\
{[114]} \\
{[115]} \\
{[116]}\end{array}$ \\
\hline $\begin{array}{l}\text { In-vivo imaging and therapy with } \\
\text { magnetic nanoparticle conjugates }\end{array}$ & US20090169478 & $\begin{array}{l}\text { Board of supervisors of Louisiana state } \\
\text { university }\end{array}$ & 2009 & [117] \\
\hline $\begin{array}{l}\text { Hydrogel nanoparticles used as } \\
\text { injectable } \\
\text { agent }\end{array}$ & CN101953775 & Zhengzhou University & 20111 & {$[118]$} \\
\hline $\begin{array}{ll}\text { Target cellular } & \text { delivery } \\
\text { nanoparticles } & \\
\end{array}$ & US20110077581 & Georgia Tech Research Corporation & 2011 & [119] \\
\hline $\begin{array}{l}\text { Bioconjugation of calcium } \\
\text { phosphosilicate nanoparticles for } \\
\text { selective targeting of cells in vivo }\end{array}$ & $\mathrm{WO} / 2011 / 057216$ & $\begin{array}{l}\text { The Pennsylvania state research } \\
\text { foundation }\end{array}$ & 2011 & {$[120]$} \\
\hline $\begin{array}{l}\text { All field simultaneous radiation } \\
\text { therapy }\end{array}$ & US08173983 & Sahadevan Velayudhan & 2012 & [121] \\
\hline $\begin{array}{l}\text { Specific detection method of human } \\
\text { breast cancer cells MCF-7 based on } \\
\text { surface-enhanced } \\
\text { spectroscopy }\end{array}$ & CN102608102 & Nanjing Normal University & 2012 & [122] \\
\hline $\begin{array}{lr}\begin{array}{l}\text { Development and use of polymer } \\
\text { nanoparticles }\end{array} \\
\text { poly[epiloncaprolactone } \\
\text { doxorubicin }\end{array}$ & WO/2012/104461 & $\begin{array}{l}\text { Servicio Andaluz De Salud, } \\
\text { Universidad De Granada }\end{array}$ & 2012 & [123] \\
\hline $\begin{array}{l}\text { NTS-polyplex nanoparticles system } \\
\text { for gene therapy of cancer }\end{array}$ & $\mathrm{WO} / 2012 / 107908$ & $\begin{array}{l}\text { Centro De Investigación } \\
\text { Estudios Avanzados Del } \\
\text { Politécnico Nacional }\end{array}$ & 2012 & [124] \\
\hline $\begin{array}{l}\text { Nano-gelatin encapsulated } \\
\text { composition of glutathione reductase } \\
\text { and lycopene }\end{array}$ & IN3233/CHE/2012 & Mary Anne Preethe. K & 2012 & [125] \\
\hline $\begin{array}{l}\text { Tripterine nanostructure lipid carrier } \\
\text { modified by lentiviral vector and } \\
\text { appliance for preparing and treating }\end{array}$ & CN102670510 & $\begin{array}{l}\text { Jiangsu Provincial Academy of } \\
\text { Traditional Chinese Medicine }\end{array}$ & 2012 & [126] \\
\hline
\end{tabular}

https://biointerfaceresearch.com/ 


\begin{tabular}{|c|c|c|c|c|}
\hline Patent name & Patent number & Applicant & Year & Refs. \\
\hline $\begin{array}{l}\text { prostatic cancer, lung cancer, and } \\
\text { breast cancer drug }\end{array}$ & & & & \\
\hline $\begin{array}{l}\text { Popcorn shape gold nanoparticles } \\
\text { for targeted diagnosis, photothermal } \\
\text { treatment, and in-situ monitoring } \\
\text { therapy response for cancer and } \\
\text { multiple drug resistance bacteria }\end{array}$ & US20120302940 & Ray Paresh Chandra & 2012 & [127] \\
\hline $\begin{array}{l}\text { Immune-Stimulating photoactive } \\
\text { hybrid nanoparticles }\end{array}$ & $\mathrm{WO} / 2013 / 012628$ & $\begin{array}{l}\text { University of Georgia Research } \\
\text { Foundation, Inc. }\end{array}$ & 2013 & [128] \\
\hline $\begin{array}{l}\text { Breast cancer therapy based on } \\
\text { hormone receptor status with } \\
\text { nanoparticles comprising taxane }\end{array}$ & US20130280337 & Abraxis BioScience, Lic. & 2013 & [129] \\
\hline $\begin{array}{l}\text { NTS-polyplex nanoparticles system } \\
\text { for gene therapy of cancer }\end{array}$ & CN103458931 & Ct Investig Y Estudios Del Ipn & 2013 & [130] \\
\hline $\begin{array}{l}\text { Methods of treating breast cancer } \\
\text { using nanoparticles comprising } \\
\text { taxane-based on hormone receptor } \\
\text { status }\end{array}$ & JP2014080443 & Abraxis BioScience, LLC & 2014 & [131] \\
\hline $\begin{array}{l}\text { Modular polymer hydrogel } \\
\text { nanoparticles and methods of their } \\
\text { manufacture }\end{array}$ & US20140220346 & $\begin{array}{l}\text { Memorial Sloan-Kettering Cancer } \\
\text { Center } \\
\text { Massachusetts Institute of Technology }\end{array}$ & 2014 & [132] \\
\hline $\begin{array}{l}\text { Immune-stimulating photoactive } \\
\text { hybrid nanoparticles }\end{array}$ & US20140220143 & $\begin{array}{l}\text { University of Georgia Research } \\
\text { Foundation, Inc. }\end{array}$ & 2014 & [133] \\
\hline $\begin{array}{l}\text { Methods for detecting single } \\
\text { mismatches in DNA hybridization } \\
\text { reaction using gold nanoparticles }\end{array}$ & KR1020140097679 & $\begin{array}{l}\text { Korea university research and business } \\
\text { foundation }\end{array}$ & 2014 & [134] \\
\hline $\begin{array}{l}\text { Targeting modified gold nanorod } \\
\text { targeted drug delivery compound } \\
\text { and application of the delivery } \\
\text { compound to antitumor } \\
\text { photothermal therapy }\end{array}$ & CN104368000 & $\begin{array}{l}\text { Second Military Medical University, } \\
\text { PLA }\end{array}$ & 2015 & [135] \\
\hline $\begin{array}{l}\text { Method used for detecting the } \\
\text { content of adenosine triphosadenine } \\
\text { in the breast cancer cell with the } \\
\text { colorimetric biosensor and } \\
\begin{array}{l}\text { constructed based on gold } \\
\text { nanoparticles }\end{array}\end{array}$ & CN105717103 & Nanjing Medical University & 2016 & [136] \\
\hline $\begin{array}{l}\text { Aptamer-modified } r \text { gold } \\
\text { nanoparticle-graphene composite } \\
\text { material and preparation method and } \\
\text { application thereof }\end{array}$ & CN105879027 & $\begin{array}{l}\text { Suzhou Institute of Nano-Tech and } \\
\text { Nano-Bionics, Chinese Academy of } \\
\text { Sciences }\end{array}$ & 2016 & [137] \\
\hline $\begin{array}{l}\text { Nanoparticle-assisted ultrasound for } \\
\text { breast cancer therapy }\end{array}$ & US20150328485 & Academia Sinica & 2016 & [138] \\
\hline $\begin{array}{l}\text { Fabrication method and application } \\
\text { of cellulose membrane of a drug } \\
\text { loading breast cancer- targeting } \\
\text { magnetic nanoparticles }\end{array}$ & CN106310256 & South china normal university & 2017 & [139] \\
\hline $\begin{array}{l}\text { A process of preparing efficient } \\
\text { herbal nanoparticles of solasodine } \\
\text { for breast cancer }\end{array}$ & IN781/KOL/2015. & Sarthak Bhattacharya & & [140] \\
\hline $\begin{array}{l}\text { Methods and compositions for } \\
\text { assaying blood levels of legumain }\end{array}$ & US20170089909 & Xiaohong Yu Fang Guo & 2017 & [141] \\
\hline $\begin{array}{l}\text { Methods and compositions for } \\
\text { assaying blood levels of legumain }\end{array}$ & US20170089910 & $\begin{array}{l}\text { Xiaohong Yu Ningbo ziyuan medical } \\
\text { devices Inc. }\end{array}$ & 2017 & [142] \\
\hline $\begin{array}{l}\text { Preparation method and application } \\
\text { of photosensitive magnetic } \\
\text { nanoparticles system capable of } \\
\text { inhibiting the growth of breast } \\
\text { cancer cells }\end{array}$ & CN106668871 & South China Normal University & & [143] \\
\hline $\begin{array}{l}\text { Combination therapy comprising } \\
\text { nanoparticles of a taxane and } \\
\text { albumin with abt- } 263 \text { in methods for } \\
\text { treating cancer }\end{array}$ & US20170202782 & Abraxis BioScience, LLC & 2017 & [144] \\
\hline $\begin{array}{l}\text { Hyaluronic acid-based nanoparticles } \\
\text { as biosensors for imaging-guided } \\
\text { surgery and drug delivery vehicles } \\
\text { and methods associated therewith }\end{array}$ & US20170202982 & Wake Forest University & 2017 & [145] \\
\hline An anticancer compound & US201741022701 & $\begin{array}{l}\text { Sree Balaji Medical College \& } \\
\text { Hospital, Biher- Bharath University }\end{array}$ & 2017 & [146] \\
\hline
\end{tabular}




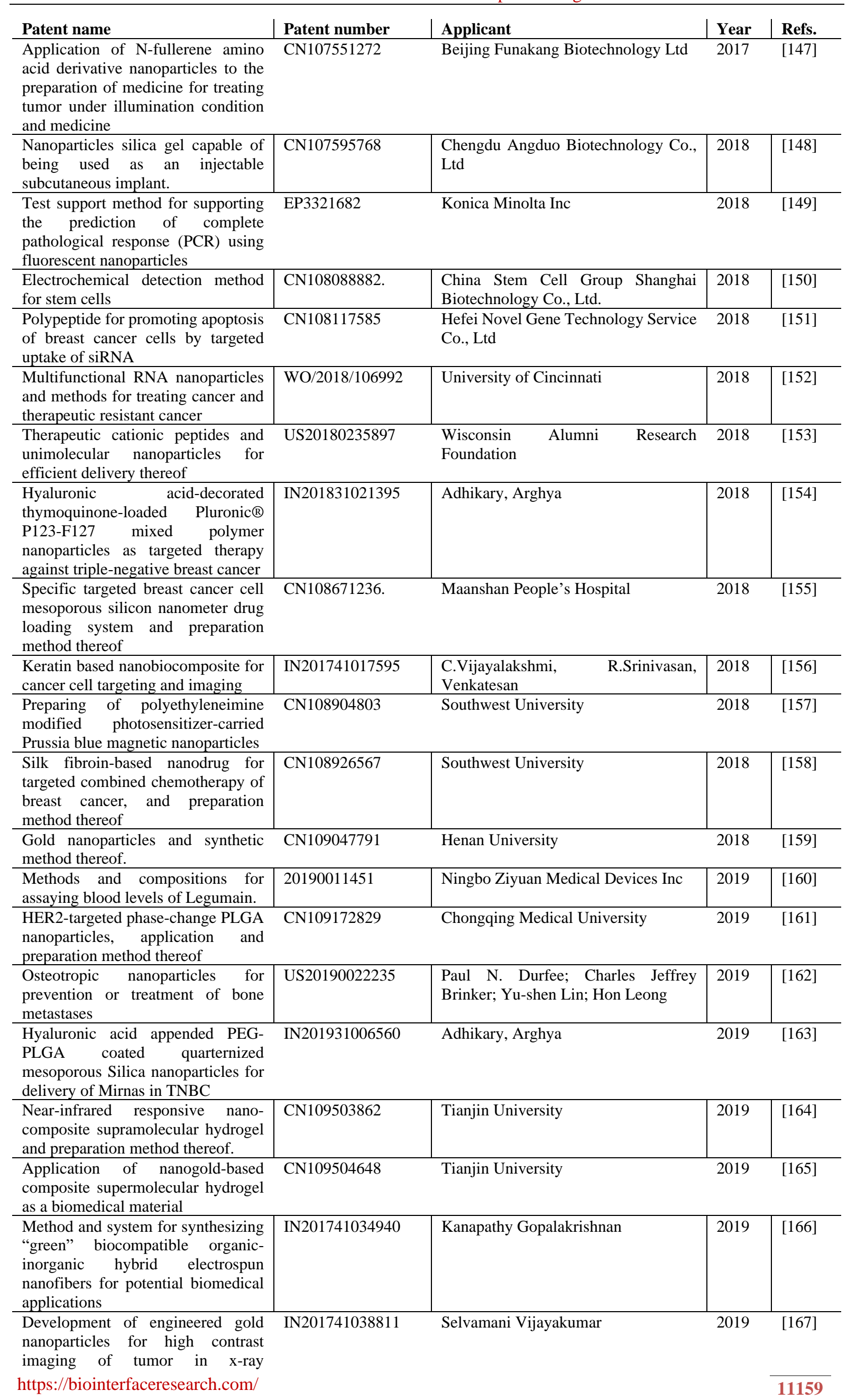




\begin{tabular}{|c|c|c|c|c|}
\hline Patent name & Patent number & Applicant & Year & Refs. \\
\hline \multicolumn{5}{|l|}{$\begin{array}{l}\text { photography and pharmacokinetic } \\
\text { studies in vivo }\end{array}$} \\
\hline $\begin{array}{l}\text { Improved pharmaceutical } \\
\text { compositions of docetaxel polymeric } \\
\text { nanoparticles and preparations } \\
\text { thereof }\end{array}$ & IN201711038532 & $\begin{array}{l}\text { Department of Pharmaceutical } \\
\text { Engineering \&Technology }\end{array}$ & 2019 & {$[168]$} \\
\hline $\begin{array}{l}\text { Macrophages membrane coated } \\
\text { breast cancer targeted nanoparticles } \\
\text { and preparation method thereof }\end{array}$ & CN109953972 & Fudan University & 2019 & [169] \\
\hline $\begin{array}{l}\text { ROS-sensitive tumor-targeted gene } \\
\text { delivery system and preparation } \\
\text { method thereof }\end{array}$ & CN109985249 & Fudan University & 2019 & {$[170]$} \\
\hline $\begin{array}{l}\text { Preparation method of quercetin } \\
\text { nanoparticles and application of } \\
\text { quercetin nanoparticles in preparing } \\
\text { a drug for resisting breast cancer }\end{array}$ & CN109999002 & Fuzhou University & 2019 & [171] \\
\hline $\begin{array}{l}\text { Pullulan nanoparticles with co- } \\
\text { supported lovastatin } \\
\text { doxorubicin and preparation method } \\
\text { thereof. }\end{array}$ & CN110201181 & Hunan Normal University & 2019 & {$[172]$} \\
\hline $\begin{array}{l}\text { Preparation and application of } \\
\text { nanoparticle doped RNA hydrogel } \\
\text { for targeted triple-negative breast } \\
\text { cancer }\end{array}$ & CN110327464. & Linyi University & 2019 & [173] \\
\hline $\begin{array}{lr}\text { Novel } & \text { RGD-chitosan } \\
\text { oligosaccharide } & \text { silicon } \\
\text { oxide/BCSG1-siRNA nanoparticle } \\
\text { breast cancer targeted therapy } \\
\text { method }\end{array}$ & CN110339372 & Henan Cancer Hospital & 2019 & {$[174]$} \\
\hline $\begin{array}{l}\text { Decreased adhesivity receptor- } \\
\text { targeted nanoparticles for Fn14- } \\
\text { positive tumors }\end{array}$ & US20190328677 & University of Maryland, Baltimor & 2019 & {$[175]$} \\
\hline $\begin{array}{l}\text { Preparation and application of nano- } \\
\text { immunological preparation based on } \\
\text { porous calcium carbonate }\end{array}$ & CN110420335 & Shandong Normal University & 2019 & [176] \\
\hline $\begin{array}{l}\text { Multifunctional RNA nanoparticles } \\
\text { and methods for treating cancer and } \\
\text { therapeutic resistant cancer }\end{array}$ & US20190351067 & University of Cincinnati & 2019 & [177] \\
\hline $\begin{array}{l}\text { Fructose and RGD peptide co- } \\
\text { modified dual-targeting triple- } \\
\text { negative breast cancer lipid material }\end{array}$ & CN110522923 & $\begin{array}{l}\text { Sichuan } \quad \text { University., } \\
\text { Fructose }\end{array}$ & 2019 & {$[178]$} \\
\hline $\begin{array}{l}\text { Green synthesis of gold } \\
\text { nanoparticles using fruit extracts- } \\
\text { bael fruit, eugenia jambolana, and } \\
\text { sours }\end{array}$ & IN201741038806. & Selvamani Vijayakumar & 2019 & [179] \\
\hline $\begin{array}{l}\text { Lipid Nanoparticles Loaded with } \\
\text { Ceranib-2 as Anticancer Agent. }\end{array}$ & WO/2020/018049. & Invokat Intellectual Property Services & 2020 & [180] \\
\hline $\begin{array}{l}\text { Gold nanoparticle-ligand conjugates } \\
\text { and methods of use }\end{array}$ & WO/2020/041267. & University of Okalahoma & 2020 & [181] \\
\hline $\begin{array}{l}\text { Preparation and application of breast } \\
\text { cancer targeted liposome modified } \\
\text { by biotin and glucose }\end{array}$ & CN110840844 & Sichuan University & 2020 & {$[182]$} \\
\hline $\begin{array}{l}\text { Preparation method of CPZ-coupled } \\
\text { MS2 protein nanoparticles and } \\
\text { application thereof in breast cancer } \\
\text { resistance }\end{array}$ & CN110841073 & Fuzhou University & 2020 & [183] \\
\hline $\begin{array}{l}\text { Application of copper-palladium } \\
\text { alloy nanoparticles and autophagy } \\
\text { inhibitors in preparing tumor-killing } \\
\text { drugs or kits based on photothermal } \\
\text { effects }\end{array}$ & CN110893237 & South China University of Technology & 2020 & {$[184]$} \\
\hline $\begin{array}{l}\text { Preparation and application of multi- } \\
\text { branch biotin modified breast cancer } \\
\text { targeted liposomes. }\end{array}$ & CN110917139 & Sichuan University & 2020 & [185] \\
\hline $\begin{array}{l}\text { Calcium phosphate-lipid nano-drug } \\
\text { co-delivery system consisting of low } \\
\text { molecular weight heparin and } \\
\text { prodrug of natural drug }\end{array}$ & CN110960507 & Fudan University & 2020 & [186] \\
\hline https://biointerfaceresearch.com/ & & & & 11160 \\
\hline
\end{tabular}




\begin{tabular}{|c|c|c|c|c|}
\hline Patent name & Patent number & Applicant & Year & Refs. \\
\hline $\begin{array}{l}\text { Adriamycin-indocyanine green } \\
\text { bionic nanoparticles and application } \\
\text { thereof }\end{array}$ & CN111000822 & Shenyang Pharmaceutical University & 2020 & [187] \\
\hline $\begin{array}{l}\text { Use of mutant P53 gene-targeted } \\
\text { lead borate nanoparticles in cancer } \\
\text { treatment and production method of } \\
\text { these nanoparticles }\end{array}$ & WO/2020/086014 & Yeditepe University & 2020 & [188] \\
\hline Ph-Activated nanoparticles & WO/2020/092602 & Ohio State Innovation Foundation & 2020 & [189] \\
\hline $\begin{array}{l}\text { A formulation and evaluation of the } \\
\text { peptide Hif9 loaded chitosan } \\
\text { nanoparticles }\end{array}$ & IN202041013943 & $\begin{array}{l}\text { Manimaran, D.; } \quad \mathrm{N} \quad \text { Elangovan.; } \\
\text { Jagatheeh, K }\end{array}$ & 2020 & [190] \\
\hline $\begin{array}{ll}\text { Targeted nanoparticles } & \text { for } \\
\text { glioblastoma theranostics } & \end{array}$ & US20200206144 & Lauren Lukas VanderSpek & 2020 & [191] \\
\hline $\begin{array}{l}\text { Therapeutic cationic peptides and } \\
\text { unimolecular nanoparticles for } \\
\text { efficient delivery thereof }\end{array}$ & US20200276130 & $\begin{array}{lll}\text { Wisconsin } & \text { Alumni } & \text { Research } \\
\text { Foundation } & & \end{array}$ & 2020 & [192] \\
\hline
\end{tabular}

\section{Clinical Trials of Nanotechnology-Based Formulation for Breast Cancer Therapeutics}

The outlook of the nano-medicine industry for cancer therapy is quite optimistic. It is well known and scientifically illustrated that such formulations tend to augment anticancer medicines drugs' efficacy to facilitate specific selective drug delivery. Table 3 outlines clinical trials involving the study of nano-formulations for the treatment of breast cancer.

Table 3. Recent clinical trials conducted for breast cancer therapeutics.

\begin{tabular}{|c|c|c|c|c|}
\hline Study Title & Sponsor & NCT No. & Phase & Refs. \\
\hline $\begin{array}{l}\text { A clinical trial to study the effects of } \\
\text { nanoparticles-based paclitaxel drug, which } \\
\text { does not contain the solvent cremophor, in } \\
\text { advanced breast cancer }\end{array}$ & $\begin{array}{l}\text { Fresenius } \\
\text { Oncology Ltd. }\end{array}$ & NCT00915369 & Phase 1 & [193] \\
\hline $\begin{array}{l}\text { Bevacizumab, doxorubicin, and } \\
\text { cyclophosphamide followed by paclitaxel } \\
\text { albumin-stabilized nanoparticles } \\
\text { formulation and bevacizumab in treating } \\
\text { patients who have undergone surgery for } \\
\text { early-stage breast cancer }\end{array}$ & $\begin{array}{lr}\text { Memorial } & \text { Sloan } \\
\text { Kettering } & \text { Cancer } \\
\text { Center } & \end{array}$ & NCT00436709 & NA & [194] \\
\hline $\begin{array}{l}\text { Paclitaxel albumin-stabilized nanoparticles } \\
\text { formulation in treating patients of different } \\
\text { ages with metastatic breast cancer }\end{array}$ & $\begin{array}{l}\text { City of Hope Medical } \\
\text { Center }\end{array}$ & NCT00609791 & Phase 2 & [195] \\
\hline $\begin{array}{l}\text { Targeted biopsy of carbon nanoparticles } \\
\text { labeled axillary node for } \mathrm{cn}+\text { breast cancer }\end{array}$ & $\begin{array}{l}\text { The First Affiliated } \\
\text { Hospital with Nanjing } \\
\text { Medical University }\end{array}$ & NCT04482803 & $\mathrm{NA}$ & [196] \\
\hline $\begin{array}{l}\text { Nanoparticles Albumin-Bound }(\mathrm{Nab}) \\
\text { Paclitaxel/Cyclophosphamide in Early-Stage } \\
\text { Breast Cancer }\end{array}$ & $\begin{array}{l}\text { SCRI Development } \\
\text { Innovations, LLC }\end{array}$ & NCT00629499 & Phase 2 & [197] \\
\hline \begin{tabular}{lcc} 
Topical & Fluorescent & \multicolumn{2}{c}{ Nanoparticles } \\
Conjugated & Somatostatin Analog for \\
Suppression and Bioimaging & Breast Cancer
\end{tabular} & Al-Azhar University & NCT04138342 & Phase 1 & [198] \\
\hline $\begin{array}{l}\text { An early-phase study of abraxane combined } \\
\text { with phenelzine sulfate in patients with } \\
\text { metastatic or advanced breast cancer (epi- } \\
\text { primed) }\end{array}$ & EpiAxis Therapeutics & NCT03505528 & Phase 1 & [199] \\
\hline $\begin{array}{l}\text { Carboplatin and nab-paclitaxel with or } \\
\text { without vorinostat in treating women with } \\
\text { newly diagnosed operable breast cancer }\end{array}$ & $\begin{array}{lr}\text { Sidney } & \text { Kimmel } \\
\text { Comprehensive Cancer } \\
\text { Center at Johns } \\
\text { Hopkins }\end{array}$ & NCT00616967 & Phase 2 & [200] \\
\hline $\begin{array}{l}\text { Doxorubicin hydrochloride, } \\
\text { cyclophosphamide, and filgrastim followed } \\
\text { by paclitaxel albumin-stabilized } \\
\text { nanoparticles formulation with or without } \\
\text { trastuzumab in treating patients with breast } \\
\text { cancer previously treated with surgery }\end{array}$ & $\begin{array}{l}\text { University } \\
\text { Washington }\end{array}$ & NCT00407888 & Phase 2 & [201] \\
\hline $\begin{array}{l}\text { Nab-paclitaxel and bevacizumab followed } \\
\text { by bevacizumab and erlotinib in metastatic } \\
\text { breast cancer }\end{array}$ & $\begin{array}{l}\text { University } \\
\text { Washington }\end{array}$ & NCT00733408 & Phase 2 & {$[202]$} \\
\hline \multicolumn{4}{|l|}{ https://biointerfaceresearch.com/ } & 11161 \\
\hline
\end{tabular}




\begin{tabular}{|c|c|c|c|c|}
\hline Study Title & Sponsor & NCT No. & Phase & Refs. \\
\hline $\begin{array}{l}\text { A study to evaluate safety/tolerability of } \\
\text { immunotherapy combinations in participants } \\
\text { with triple-negative breast cancer or } \\
\text { gynecologic malignancies }\end{array}$ & Arcus Biosciences, Inc. & NCT03719326 & Phase 1 & [203] \\
\hline $\begin{array}{l}\text { Carboplatin+Nab-paclitaxel, } \\
\text { Trastuzumab (HER2+) or Bevacizumab } \\
\text { (HER2-) in the Neoadjuvant Setting }\end{array}$ & $\begin{array}{l}\text { University of } \\
\text { California, Irvine }\end{array}$ & NCT00618657 & Phase 2 & [204] \\
\hline $\begin{array}{l}\text { Targeted silica nanoparticles for real-time } \\
\text { image-guided intraoperative mapping of } \\
\text { nodal metastases }\end{array}$ & $\begin{array}{lr}\text { Memorial } & \text { Sloan } \\
\text { Kettering } & \text { Cancer } \\
\text { Center } & \\
\end{array}$ & NCT02106598 & Phase 1 Phase 2 & [205] \\
\hline $\begin{array}{l}\text { Schedules of nab-paclitaxel in metastatic } \\
\text { breast cancer (snap) }\end{array}$ & $\begin{array}{l}\text { International Breast } \\
\text { Cancer Study Group }\end{array}$ & NCT01746225 & Phase 2 & [206] \\
\hline $\begin{array}{l}\text { Phase II lapatinib plus nab-paclitaxel as first } \\
\text { and second-line therapy in her } 2+\text { mbc }\end{array}$ & $\begin{array}{l}\text { Novartis } \\
\text { Pharmaceuticals }\end{array}$ & NCT00709761 & Phase 2 & [207] \\
\hline $\begin{array}{l}\text { Neoadjuvant pembrolizumab(pbr)/nab- } \\
\text { paclitaxel followed }\end{array} \begin{array}{r}\text { by } \\
\text { pbr/epirubicin/cyclophosphamide in tnbc } \\
\text { (nib) }\end{array}$ & $\begin{array}{ll}\text { Institut } & \text { fuer } \\
\text { Frauengesundheit } & \end{array}$ & NCT03289819 & Phase 2 & [208] \\
\hline $\begin{array}{l}\text { Nanoparticles albumin-bound rapamycin in } \\
\text { treating patients with advanced cancer with } \\
\text { mtor mutations }\end{array}$ & Mayo Clinic & NCT02646319 & Early Phase 1 & [209] \\
\hline $\begin{array}{l}\text { Nab-paclitaxel and alpelisib for the treatment } \\
\text { of anthracycline refractory triple-negative } \\
\text { breast cancer with pik3ca or pten alterations }\end{array}$ & $\begin{array}{l}\text { M.D. Anderson Cancer } \\
\text { Center }\end{array}$ & NCT04216472 & Phase 2 & [210] \\
\hline $\begin{array}{l}\text { Cryoablation, atezolizumab/nab-paclitaxel } \\
\text { for locally advanced or metastatic triple- } \\
\text { negative breast cancer }\end{array}$ & Mayo Clinic & NCT04249167 & Early Phase 1 & [211] \\
\hline $\begin{array}{l}\text { Nab-paclitaxel and durvalumab with or } \\
\text { without neoantigen vaccine in treating } \\
\text { patients with metastatic triple-negative } \\
\text { breast cancer }\end{array}$ & $\begin{array}{ll}\text { National } & \text { Cancer } \\
\text { Institute (NCI) } & \end{array}$ & NCT03606967 & Phase 2 & [212] \\
\hline $\begin{array}{l}\text { Study to evaluate cort } 125134 \text { in combination } \\
\text { with nab-paclitaxel in patients with solid } \\
\text { tumors }\end{array}$ & Corcept Therapeutics & NCT02762981 & Phase 1 Phase 2 & [213] \\
\hline
\end{tabular}

\section{Conclusions}

Conventional chemotherapy approaches have numerous drawbacks like lack of selective toxicity, damage to normal tissues, poor bio-distribution and drug penetration, and the tendency of greater drug deposition in normal viscera. Polymeric nanoparticles have various advantages, including passive or active drug targeting in tumor tissues and improved intracellular penetration. Several publications, patents, and clinical trials based on the application of polymeric nanoparticles for breast cancer treatment give the impression that the integration of polymeric nanoparticle-based techniques in cancer therapy will be an innovative and futuristic approach producing superior efficacious and drug targeting with reduced toxicity.

\section{Current \& Future Developments}

The integration of current nanoparticles based techniques will be part of the future of anticancer therapy. Consequently, it's essential to decide which approaches perform effectively in a coordinated way to acquire the maximum anticancer effect. The optimal pharmacological treatments to kill cancer cells can be developed by comprehending the underlying mechanisms under which medicines destroy tumor cells. Nowadays, the most effective chemotherapeutic approach is nanoparticle-based medicines. Undoubtedly, to maximize traditional chemotherapy's therapeutic effectiveness, the domain of nano-medicine can be explored in prospects. 


\section{Funding}

This research received no external funding.

\section{Acknowledgments}

\section{The authors express gratitude to Chitkara College of Pharmacy, Chitkara University, Punjab, India, for motivational support for this review's compilation.}

\section{Conflicts of Interest}

The authors declare no conflict of interest.

\section{References}

1. Siegel, R.L.; Miller, K.D.; Jemal, A. Cancer statistics, 2020. CA Cancer J. Clin. 2020, 70, 7-30, https://doi.org/10.3322/caac.21590.

2. Chua, C.Y.X.; Jeremy Ho, Demaria, S.; Ferrari, M.; Grattoni, A. Emerging technologies for local cancer treatment. Adv. Ther. 2020, 3, https://doi.org/10.1002/adtp.202000027.

3. Trimboli, R.M.; Rossi, P.G.; Battisti, N.M.L.; Cozzi, A.; Magni, V.; Zanardo, M.; Sardanelli, F. Do we still need breast cancer screening in the era of targeted therapies and precision medicine? Insights Imaging 2020, 11, https://doi.org/10.1186/s13244-020-00905-3.

4. Chaturvedi, V.K.; Singh, A.; Singh, V.K.; Singh, M.P. Cancer nanotechnology: a new revolution for cancer diagnosis and therapy. Curr. Drug Metab. 2019, 20, 416-429, https://doi.org/10.2174/1389200219666180918111528.

5. Nagini, S. Breast cancer: current molecular therapeutic targets and new players. Anticancer Agents Med. Chem. 2017, 17, 152-163, https://doi.org/10.2174/1871520616666160502122724.

6. Hou, X.; Shou, C.; He, M.; Xu, J.; Cheng, Y.; Yuan, Z.; Lan, M.; Zhao, Y.; Yang, Y.; Chen, X.; Gao, F. A combination of LightOn gene expression system and tumor microenvironment-responsive nanoparticle delivery system for targeted breast cancer therapy. Acta Pharm. Sin. B. 2020, 10, 1741-1753, https://doi.org/10.1016/j.apsb.2020.04.010.

7. Yin, L.; Duan, J.J.; Bian, X.W.; Yu, S.C. Triple-negative breast cancer molecular subtyping and treatment progress. Breast Cancer Res. 2020, 22, https://doi.org/10.1186/s13058-020-01296-5.

8. Uzelac, B.; Krivokuca, A.; Brankovic-Magic, M.; Magic, Z.; Susnjar, S.; Milovanovic, Z.; Supic, G. Expression of SIRT1, SIRT3 and SIRT6 genes for predicting survival in triple-negative and hormone receptor-positive subtypes of breast cancer. Pathol. Oncol. Res. 2020, 26, 2723-2731, https://doi.org/10.1007/s12253-020-00873-5.

9. Li, C.; Li, J.; Xu, Y.; Zhan, Y.; Li, Y.; Song, T.; Zheng, J.; Yang, H. Application of phage-displayed peptides in tumor imaging diagnosis and targeting therapy. Int. J. Pept. Res. Ther. 2020, 1-9, https://doi.org/10.1007/s10989-020-10108-5.

10. Moo, T.A.; Sanford, R.; Dang, C.; Morrow, M. Overview of breast cancer therapy. PET Clinics 2018, 13, 339-354. https://doi.org/10.1016/j.cpet.2018.02.006

11. Waks, A.G.; Winer, E.P. Breast cancer treatment: a review. Jama 2019, 321, 288-300, https://doi.org/10.1001/jama.2018.19323.

12. Sharma, G.N.; Dave, R.; Sanadya, J.; Sharma, P.; Sharma, K.K. Various types and management of breast cancer: an overview. J. Adv. Pharm. Technol. Res. 2010, 1, 109-126.

13. Schmid, P.; Cortes, J.; Pusztai, L.; McArthur, H.; Kümmel, S.; Bergh, J.; Denkert, C.; Park, Y.H.; Hui, R.; Harbeck, N.; Takahashi, M.; Foukakis, T.; Fasching, P.A.; Cardoso, F.; Untch, M.; Jia, L.; Karantza, V.; Zhao, J.; Aktan, G.; Dent, R.; O’Shaughnessy, J.; KEYNOTE-522 Investigators. Pembrolizumab for early triple-negative breast cancer. New Eng. J. Med. 2020, 382, 810-821, https://doi.org/10.1056/NEJMoa1910549.

14. Lee, K.L.; Kuo, Y.C.; Ho, Y.S.; Huang, Y.H. Triple-negative breast cancer: Current understanding and future therapeutic breakthrough targeting cancer stemness. Cancers 2019, 11, https://doi.org/10.3390/cancers11091334.

15. Qin, J.J.; Yan, L.; Zhang, J.; Zhang, W.D. STAT3 as a potential therapeutic target in triple negative breast cancer: a systematic review. J. Exp. Clin. Cancer Res. 2019, 38, https://doi.org/10.1186/s13046-019-1206$\mathrm{z}$.

16. Nagayama, A.; Vidula, N.; Ellisen, L.; Bardia, A. Novel antibody-drug conjugates for triple negative breast cancer. Ther. Adv. Med. Oncol. 2020, 12, https://doi.org/10.1177/1758835920915980.

17. Lev, S. Targeted therapy and drug resistance in triple-negative breast cancer: the EGFR axis. Biochem. Soc. Trans. 2020, 48, 657-665, https://doi.org/10.1042/BST20191055. 
18. Jain, V.; Kumar, H.; Anod, H.V.; Chand, P.; Gupta, N.V.; Dey, S.; Kesharwani, S.S. A review of nanotechnology-based approaches for breast cancer and triple-negative breast cancer. J. Control. Release 2020, 326, 628-647, https://doi.org/10.1016/j.jconrel.2020.07.003.

19. Bardia, A.; Mayer, I.A.; Vahdat, L.T.; Tolaney, S.M.; Isakoff, S.J.; Diamond, J.R.; O’Shaughnessy, J.; Moroose, R.L.; Santin, A.D.; Abramson, V.G.; Shah, N.C.; Rugo, H.S.; Goldenberg, D.M.; Sweidan, A.M.; Iannone, R.; Washkowitz, S.; Sharkey, R.M.; Wegener, W.A.; Kalinsky, K. Sacituzumab govitecan-hziy in refractory metastatic triple-negative breast cancer. New Eng. J. Med. 2019, 380, 741-751, https://doi.org/10.1056/NEJMoa1814213.

20. Henriksen, E.L.; Carlsen, J.F.; Vejborg, I.M.; Nielsen, M.B.; Lauridsen, C.A. The efficacy of using computer-aided detection (CAD) for detection of breast cancer in mammography screening: a systematic review. Acta Radiologica 2019, 60, 13-18, https://doi.org/10.1177/0284185118770917.

21. Houssami, N.; Kirkpatrick-Jones, G.; Noguchi, N.; Lee, C.I. Artificial Intelligence (AI) for the early detection of breast cancer: a scoping review to assess AI's potential in breast screening practice. Expert Rev. Med. Devices 2019, 16, 351-362, https://doi.org/10.1080/17434440.2019.1610387.

22. Liu, Y.; Kohlberger, T.; Norouzi, M.; Dahl, G.E.; Smith, J.L.; Mohtashamian, A.; Olson, N.; Peng, L.H.; Hipp, J.D.; Stumpe, M.C. Artificial intelligence-based breast cancer nodal metastasis detection: Insights into the black box for pathologists. Arch. Pathol. Lab. Med. 2019, 143, 859-868, https://doi.org/10.5858/arpa.2018-0147-OA.

23. Chitalia, R.D.; Kontos, D. Role of texture analysis in breast MRI as a cancer biomarker: A review. J. Mag. Reson. Imaging 2019, 49, 927-938, https://doi.org/10.1002/jmri.26556.

24. Abbaci, M.; Conversano, A.; De Leeuw, F.; Laplace-Builhé, C.; Mazouni, C. Near-infrared fluorescence imaging for the prevention and management of breast cancer-related lymphedema: a systematic review. Eur. J. Surg. Oncol. 2019, 45, 1778-1786, https://doi.org/10.1016/j.ejso.2019.06.009.

25. Sheth, D.; Giger, M.L. Artificial intelligence in the interpretation of breast cancer on MRI. J. Magn. Reson. Imaging 2020, 51, 1310-1324, https://doi.org/10.1002/jmri.26878.

26. Alimirzaie, S.; Bagherzadeh, M.; Akbari, M.R. Liquid biopsy in breast cancer: A comprehensive review. Clin. Genet. 2019, 95, 643-660, https://doi.org/10.1111/cge.13514.

27. Sheth, D.; Giger, M.L. Artificial intelligence in the interpretation of breast cancer on MRI. J. Mag. Reson. Imaging 2020, 51, 1310-1324, https://doi.org/10.1002/jmri.26878.

28. He, Z.; Chen, Z.; Tan, M.; Elingarami, S.; Liu, Y.; Li, T.; Deng, Y.; He, N.; Li,, S.; Fu, J.; Li, W. A review on methods for diagnosis of breast cancer cells and tissues. Cell Prolif. 2020, 53, https://doi.org/10.1111/cpr.12822.

29. Pesapane, F.; Downey, K..; Rotili, A.; Cassano, E.; Koh, D.M. Imaging diagnosis of metastatic breast cancer. Insights Imaging 2020, 11, 1-14, https://doi.org/10.1186/s13244-020-00885-4.

30. Rahbar, H.; Lee, J.M.; Lee, C.I. Optimal screening in breast cancer survivors with dense breasts on mammography. J. Clin. Oncol. 2020, 38, 3833-3840, https://doi.org/10.1200/JCO.20.01641.

31. Sakurai, Y.; Akita, H.; Harashima, H. Targeting tumor endothelial cells with nanoparticles. Int. J. Mol. Sci. 2019, 20, https://doi.org/10.3390/ijms20235819.

32. Salama, L.; Pastor, E.R.; Stone, T.; Mousa, S.A. Emerging nanopharmaceuticals and nanonutraceuticals in cancer management. Biomedicines 2020, 8, https://doi.org/10.3390/biomedicines8090347.

33. Hida, K.; Maishi, N.; Sakurai, Y.; Hida, Y.; Harashima, H. Heterogeneity of tumor endothelial cells and drug delivery. Adv. Drug Deliv. Rev. 2016, 99, 140-147, https://doi.org/10.1016/j.addr.2015.11.008.

34. Yao, Y.; Zhou, Y.; Liu, L.; Xu, Y.; Chen, Q.; Wang, Y.; Wu, S.; Deng, Y.; Zhang, J.; Shao, A. Nanoparticlebased drug delivery in cancer therapy and its role in overcoming drug resistance. Front Mol. Biosci. 2020, 7, https://doi.org/10.3389/fmolb.2020.00193.

35. Nair, P.R. Delivering combination chemotherapies and targeting oncogenic pathways via polymeric drug delivery systems. Polymers (Basel) 2019, 11, https://doi.org/10.3390/polym11040630.

36. Wong, K.H.; Chen, A.L.X.; Yang, Z. Natural ingredient-based polymeric nanoparticles for cancer treatment. Molecules 2020, 25, https://doi.org/10.3390/molecules25163620.

37. Lan, H.; Zhang, W.; Jin, K.; Liu, Y.; Wang, Z. Modulating barriers of tumor microenvironment through nanocarrier systems for improved cancer immunotherapy: a review of current status and future perspective. Drug Deliv. 2020, 27, 1248-1262, https://doi.org/10.1080/10717544.2020.1809559.

38. Kamaruzman, N.I.; Aziz, N.A.; Poh, C.L.; Chowdhury, E.H. Oncogenic signaling in tumorigenesis and applications of siRNA nanotherapeutics in breast cancer. Cancers (Basel) 2019, 11, https://doi.org/10.3390/cancers11050632.

39. Chinnappan, R.; Faraj, A.A.; Rahman, A.M.A.; Abu-Salah, K.M.; Mouffouk, F.; Zourob, M.. Anti-VCAM1 and Anti-IL4R $\alpha$ aptamer-conjugated super paramagnetic iron oxide nanoparticles for enhanced breast cancer diagnosis and therapy. Molecules 2020, 25, https://doi.org/10.3390/molecules25153437.

40. Amate, M.; Goldgewicht, J.; Sellamuthu, B.; Stagg, J.; Yu, F.T.H. The effect of ultrasound pulse length on microbubble cavitation induced antibody accumulation and distribution in a mouse model of breast cancer. Nanotheranostics 2020, 4, 256-269, https://doi.org/10.7150/ntno.46892. 
41. Azemati, F.; Kondori, B.J.; Ghaleh, H.E.G. Therapeutic potential of nanoparticle-loaded hydroxyurea on proliferation of human breast adenocarcinoma cell line. Iran. J. Pharm. Res. 2020, 19, 271-281, https://doi.org/10.22037/ijpr.2020.1100921.

42. Zeng, Y.; Yao, X.; Liu, X.; He, X.; Li, L.; Liu, X.; Yan, X.; Wu, J.; Fu, B.M. Anti-angiogenesis triggers exosomes release from endothelial cells to promote tumor vasculogenesis. J. Extracell. Vesicles 2019, 8, https://doi.org/10.1080/20013078.2019.1629865.

43. Soe, Z.C.; Kwon, J.B.; Thapa, R.K.; Ou, W.; Nguyen, H.T.; Gautam, M.; Kim, J.O. Transferrin-conjugated polymeric nanoparticle for receptor-mediated delivery of doxorubicin in doxorubicin-resistant breast cancer cells. Pharm. 2019, 11, https://doi.org/10.3390/pharmaceutics11020063.

44. Yang, Y.; Pan, D.; Luo, K.; Li, L.; Gu, Z. Biodegradable and amphiphilic block copolymer-doxorubicin conjugate as polymeric nanoscale drug delivery vehicle for breast cancer therapy. Biomaterials 2013, 34, 8430-8443, https://doi.org/10.1016/j.biomaterials.2013.07.037.

45. Zhou, Z.; Kennell, C.; Jafari, M.; Lee, J.Y.; Ruiz-Torres, S.J.; Waltz, S.E.; Lee, J.H. Sequential delivery of erlotinib and doxorubicin for enhanced triple negative breast cancer treatment using polymeric nanoparticle. Int. J. Pharm. 2017, 530, 300-307, https://doi.org/10.1016/j.ijpharm.2017.07.085.

46. Shenoy, D.B.; Amiji, M.M. Poly (ethylene oxide)-modified poly ( $\varepsilon$-caprolactone) nanoparticles for targeted delivery of tamoxifen in breast cancer. Int. J. Pharm. 2005, 293, 261-270, https://doi.org/10.1016/j.ijpharm.2004.12.010.

47. Ranade, A.A.; Bapsy, P.P.; Nag, S.; Raghunadharao, D.; Raina, V.; Advani, S.H.; Sekhon, J.S. A multicenter phase II randomized study of Cremophor-free polymeric nanoparticle formulation of paclitaxel in women with locally advanced and/or metastatic breast cancer after failure of anthracycline. Asia Pac. J. Clin. Oncol. 2013, 9, 176-181, https://doi.org/10.1111/ajco.12035.

48. Yang, J.; Lee, C.H.; Park, J.; Seo, S.; Lim, E.K.; Song, Y.J.; Haam, S. Antibody conjugated magnetic PLGA nanoparticles for diagnosis and treatment of breast cancer. J. Mater. Chem. 2007, 17, 2695-2699, https://doi.org/10.1039/B702538F.

49. Katiyar, S.S.; Muntimadugu, E.; Rafeeqi, T.A.; Domb, A.J.; Khan, W. Co-delivery of rapamycin-and piperine-loaded polymeric nanoparticles for breast cancer treatment. Drug Deliv. 2016, 23, 2608-2616, https://doi.org/10.3109/10717544.2015.1039667.

50. Acharya, S.; Dilnawaz, F.; Sahoo, S.K. Targeted epidermal growth factor receptor nanoparticle bioconjugates for breast cancer therapy. Biomaterials 2009, 30, 5737-5750, https://doi.org/10.1016/j.biomaterials.2009.07.008.

51. Saxena, V.; Naguib, Y.; Hussain, M.D. Folate receptor targeted 17-allylamino-17-demethoxygeldanamycin (17-AAG) loaded polymeric nanoparticles for breast cancer. Colloids Surf. B Biointerfaces 2012, 94, 274280, https://doi.org/10.1016/j.colsurfb.2012.02.001.

52. Jithan, A.V.; Madhavi, K.; Madhavi, M.; Prabhakar, K. Preparation and characterization of albumin nanoparticles encapsulating curcumin intended for the treatment of breast cancer. Int. J. Pharm. Investig. 2011, 1, https://dx.doi.org/10.4103\%2F2230-973X.82432.

53. Jain, A.K.; Swarnakar, N.K.; Das, M.; Godugu, C.; Singh, R.P.; Rao, P.R.; Jain, S. Augmented anticancer efficacy of doxorubicin-loaded polymeric nanoparticles after oral administration in a breast cancer induced animal model. Mol. Pharm. 2011, 8, 1140-1151, https://doi.org/10.1021/mp200011f.

54. Muntimadugu, E.; Kumar, R.; Saladi, S.; Rafeeqi, T.A.; Khan, W. CD44 targeted chemotherapy for coeradication of breast cancer stem cells and cancer cells using polymeric nanoparticles of salinomycin and paclitaxel. Colloids Surf. B Biointerfaces 2016, 143, 532-546, https://doi.org/10.1016/j.colsurfb.2016.03.075.

55. Bressler, E.M.; Kim, J.; Shmueli, R.B.; Mirando, A.C.; Bazzazi, H.; Lee, E.; Green, J.J. Biomimetic peptide display from a polymeric nanoparticle surface for targeting and antitumor activity to human triple-negative breast cancer cells. J. Biomed. Mater. Res. A 2018, 106, 1753-1764, https://doi.org/10.1002/jbm.a.36360.

56. Nicolas, S.; Bolzinger, M.A.; Jordheim, L.P.; Chevalier, Y.; Fessi, H.; Almouazen, E. Polymeric nanocapsules as drug carriers for sustained anticancer activity of calcitriol in breast cancer cells. Int. J. Pharm. 2018, 550, 170-179, https://doi.org/10.1016/j.ijpharm.2018.08.022.

57. Bhardwaj, V.; Ankola, D.D.; Gupta, S.C.; Schneider, M.; Lehr, C.M.; Kumar, M.R. PLGA nanoparticles stabilized with cationic surfactant: safety studies and application in oral delivery of paclitaxel to treat chemical-induced breast cancer in rat. Pharm. Res. 2009, 26, 2495-2503, https://doi.org/10.1007/s11095009-9965-4.

58. Panda, J.; Satapathy, B.S.; Majumder, S.; Sarkar, R.; Mukherjee, B.; Tudu, B. Engineered polymeric iron oxide nanoparticles as potential drug carrier for targeted delivery of docetaxel to breast cancer cells. J. Magn. Magn. Mater. 2019, 485, 165-173, https://doi.org/10.1016/j.jmmm.2019.04.058.

59. Li, J.; Cai, P.; Shalviri, A.; Henderson, J.T.; He, C.; Foltz, W.D.; Rauth, A.M. A multifunctional polymeric nanotheranostic system delivers doxorubicin and imaging agents across the blood-brain barrier targeting brain metastases of breast cancer. ACS Nano. 2014, 8, 9925-9940, https://doi.org/10.1021/nn501069c.

60. Maji, R.; Dey, N.S.; Satapathy, B.S.; Mukherjee, B.; Mondal, S. Preparation and characterization of Tamoxifen citrate loaded nanoparticles for breast cancer therapy. Int. J. Nanomedicine 2014, 9, https://dx.doi.org/10.2147\%2FIJN.S63535. 
61. Soni, P.; Kaur, J.; Tikoo, K. Dual drug-loaded paclitaxel-thymoquinone nanoparticles for effective breast cancer therapy. J. Nanopart. Res. 2015, 17, https://doi.org/10.1007/s11051-014-2821-4.

62. Yuan, J.D.; ZhuGe, D.L.; Tong, M.Q.; Lin, M.T.; Xu, X.F.; Tang, X.; Xu, H.L. pH-sensitive polymeric nanoparticles of mPEG-PLGA-PGlu with hybrid core for simultaneous encapsulation of curcumin and doxorubicin to kill the heterogeneous tumour cells in breast cancer. Artif. Cells Nanomed. Biotechnol. 2018, 46, 302-313, https://doi.org/10.1080/21691401.2017.1423495.

63. Sun, B.; Ranganathan, B.; Feng, S.S. Multifunctional poly (D, L-lactide-co-glycolide)/montmorillonite (PLGA/MMT) nanoparticles decorated by Trastuzumab for targeted chemotherapy of breast cancer. Biomaterials 2008, 29, 475-486, https://doi.org/10.1016/j.biomaterials.2007.09.038.

64. Vakilinezhad, M. A.; Amini, A.; Dara, T.; Alipour, S. Methotrexate and curcumin co-encapsulated PLGA nanoparticles as a potential breast cancer therapeutic system: In vitro and in vivo evaluation. Colloids Surf. B Biointerfaces 2019, 184, https://doi.org/10.1016/j.colsurfb.2019.110515.

65. Tavassolian, F.; Kamalinia, G.; Rouhani, H.; Amini, M.; Ostad, S.N.; Khoshayand, M.R.; Dinarvand, R. Targeted poly (l- $\gamma$-glutamyl glutamine) nanoparticles of docetaxel against folate over-expressed breast cancer cells. Int. J. Pharm. 2014, 467, 123-138, https://doi.org/10.1016/j.ijpharm.2014.03.033.

66. Mei, L.; Zhang, Y.; Zheng, Y.; Tian, G.; Song, C.; Yang, D.; Li, Z. A novel docetaxel-loaded poly (عcaprolactone)/pluronic F68 nanoparticle overcoming multidrug resistance for breast cancer treatment. Nanoscale Res. Lett. 2009, 4, 1530-1539, https://doi.org/10.1007/s11671-009-9431-6.

67. Zubris, K.A.V.; Liu, R.; Colby, A.; Schulz, M.D.; Colson, Y.L.; Grinstaff, M.W. In vitro activity of paclitaxel-loaded polymeric expansile nanoparticles in breast cancer cells. Biomacromolecules 2013, 14, 2074-2082, https://doi.org/10.1021/bm400434h.

68. Zhao, Y.; Zhang, T.; Duan, S.; Davies, N.M.; Forrest, M.L. CD44-tropic polymeric nanocarrier for breast cancer targeted rapamycin chemotherapy. Nanomed. Nanotech. Bio. Med. 2014, 10, 1221-1230, https://doi.org/10.1016/j.nano.2014.02.015.

69. Tang, X.; Cai, S.; Zhang, R.; Liu, P.; Chen, H.; Zheng, Y.; Sun, L. Paclitaxel-loaded nanoparticles of starshaped cholic acid-core PLA-TPGS copolymer for breast cancer treatment. Nanoscale Res. Lett. 2013, 8, https://doi.org/10.1186/1556-276X-8-420.

70. Tao, W.; Zeng, X.; Liu, T.; Wang, Z.; Xiong, Q.; Ouyang, C.; Mei, L. Docetaxel-loaded nanoparticles based on star-shaped mannitol-core PLGA-TPGS diblock copolymer for breast cancer therapy. Acta Biomater. 2013, 9, 8910-8920, https://doi.org/10.1016/j.actbio.2013.06.034.

71. Dehghan Kelishady, P.; Saadat, E.; Ravar, F.; Akbari, H.; Dorkoosh, F. Pluronic F127 polymeric micelles for co-delivery of paclitaxel and lapatinib against metastatic breast cancer: preparation, optimization and in vitro evaluation. Pharm. Dev. Technol. 2015, 20, 1009-1017, https://doi.org/10.3109/10837450.2014.965323.

72. Chowdhury, P.; Nagesh, P.K.; Khan, S.; Hafeez, B.B.; Chauhan, S.C.; Jaggi, M.; Yallapu, M.M. Development of polyvinylpyrrolidone/paclitaxel self-assemblies for breast cancer. Acta Pharm. Sin. B. 2018, 8, 602-614, https://doi.org/10.1016/j.apsb.2017.10.004

73. Talaei, F.; Azizi, E.; Dinarvand, R.; Atyabi, F. Thiolated chitosan nanoparticles as a delivery system for antisense therapy: evaluation against EGFR in T47D breast cancer cells. Int. J. Nanomedicine 2011, 6, https://dx.doi.org/10.2147\%2FIJN.S22731.

74. El-Gogary, R.I.; Gaber, S.A.A.; Nasr, M. Polymeric nanocapsular baicalin: chemometric optimization, physicochemical characterization and mechanistic anticancer approaches on breast cancer cell lines. Sci. Rep. 2019, 9, 1-14, https://doi.org/10.1038/s41598-019-47586-7.

75. Vivek, R.; Thangam, R.; NipunBabu, V.; Rejeeth, C.; Sivasubramanian, S.; Gunasekaran, P.; Kannan, S. Multifunctional HER2-antibody conjugated polymeric nanocarrier-based drug delivery system for multidrug-resistant breast cancer therapy. ACS Appl. Mater. Interfaces 2014, 6, 6469-6480, https://doi.org/10.1021/am406012g.

76. Zhang, Y.; Guo, Q.; An, S.; Lu, Y.; Li, J.; He, X.; Jiang, C. ROS-switchable polymeric nanoplatform with stimuli-responsive release for active targeted drug delivery to breast cancer. ACS Appl. Mater. Interfaces 2017, 9, 12227-12240, https://doi.org/10.1021/acsami.6b16815.

77. Elbaz, N.M.; Ziko, L.; Siam, R.; Mamdouh, W. Core-shell silver/polymeric nanoparticles-based combinatorial therapy against breast cancer in-vitro. Sci. Rep. 2016, 6, https://doi.org/10.1038/srep30729.

78. Chen, J.; Li, S.; Shen, Q.; He, H.; Zhang, Y. Enhanced cellular uptake of folic acid-conjugated PLGA-PEG nanoparticles loaded with vincristine sulfate in human breast cancer. Drug Dev. Ind. Pharm. 2011, 37, 13391346, https://doi.org/10.3109/03639045.2011.575162.

79. Zeighamian, V.; Darabi, M.; Akbarzadeh, A.; Rahmati-Yamchi, M.; Zarghami, N.; Badrzadeh, F.; TaheriAnganeh, M. PNIPAAm-MAA nanoparticles as delivery vehicles for curcumin against MCF-7 breast cancer cells. Artif. Cells Nanomed. Biotechnol. 2016, 44, 735-742, https://doi.org/10.3109/21691401.2014.982803.

80. Wu, Y.; Wang, Z.; Liu, G.; Zeng, X.; Wang, X.; Gao, Y.; Mei, L. Novel simvastatin-loaded nanoparticles based on cholic acid-core star-shaped PLGA for breast cancer treatment. J. Biomed. Nanotech. 2015, 11, 1247-1260, https://doi.org/10.1166/jbn.2015.2068.

81. Varukattu, N.B.; Vivek, R.; Rejeeth, C.; Thangam, R.; Ponraj, T.; Sharma, A.; Kannan, S. Nanostructured pH-responsive biocompatible chitosan coated copper oxide nanoparticles: A polymeric smart intracellular 
delivery system for doxorubicin in breast cancer cells. Arab. J. Chem. 2020, 13, 2276-2286, https://doi.org/10.1016/j.arabjc.2018.04.012.

82. Thadakapally, R.; Aafreen, A.; Aukunuru, J.; Habibuddin, M.; Jogala, S. Preparation and characterization of PEG-albumin-curcumin nanoparticles intended to treat breast cancer. Indian J. Pharm. Sci. 2016, 78.

83. Wan, X.; Beaudoin, J.J.; Vinod, N.; Min, Y.; Makita, N.; Bludau, H.; Kabanov, A.V. Co-delivery of paclitaxel and cisplatin in poly (2-oxazoline) polymeric micelles: Implications for drug loading, release, pharmacokinetics and outcome of ovarian and breast cancer treatments. Biomaterials 2019, 192, 1-14, https://doi.org/10.1016/j.biomaterials.2018.10.032.

84. Anari, E.; Akbarzadeh, A.; Zarghami, N. Chrysin-loaded PLGA-PEG nanoparticles designed for enhanced effect on the breast cancer cell line. Artif. Cells Nanomed. Biotechnol. 2016, 44, 1410-1416, https://doi.org/10.3109/21691401.2015.1029633.

85. Markeb, A.A.; El-Maali, N.A.; Sayed, D.M.; Osama, A.; Abdel-Malek, M.A.; Zaki, A.H.; Driscoll, J.J. Synthesis, structural characterization, and preclinical efficacy of a novel paclitaxel-loaded alginate nanoparticle for breast cancer treatment. Int. J. Breast Cancer 2016, 2016, https://doi.org/10.1155/2016/7549372.

86. Mehata, A.K.; Bharti, S.; Singh, P.; Viswanadh, M.K.; Kumari, L.; Agrawal, P.; Muthu, M.S. Trastuzumab decorated TPGS-g-chitosan nanoparticles for targeted breast cancer therapy. Colloids Surf. B Biointerfaces 2019, 173, 366-377, https://doi.org/10.1016/j.colsurfb.2018.10.007.

87. Alemrayat, B.; Elhissi, A.; Younes, H.M. Preparation and characterization of letrozole-loaded poly (d, 1lactide) nanoparticles for drug delivery in breast cancer therapy. Pharm. Dev. Technol. 2019, 24, 235-242, https://doi.org/10.1080/10837450.2018.1455698.

88. Yewale, C.; Baradia, D.; Patil, S.; Bhatt, P.; Amrutiya, J.; Gandhi, R.; Misra, A. Docetaxel loaded immunonanoparticles delivery in EGFR overexpressed breast carcinoma cells. J. Drug Deliv. Sci. Technol. 2018, 45, 334-345, https://doi.org/10.1016/j.jddst.2018.03.027.

89. Cerqueira, B.B.S.; Lasham, A.; Shelling, A.N.; Al-Kassas, R. Development of biodegradable PLGA nanoparticles surface engineered with hyaluronic acid for targeted delivery of paclitaxel to triple negative breast cancer cells. Mater. Sci. Eng. C 2017, 76, 593-600, https://doi.org/10.1016/j.msec.2017.03.121.

90. Jain, A.; Sharma, G.; Kushwah, V.; Garg, N. K.; Kesharwani, P.; Ghoshal, G.; Katare, O.P. Methotrexate and beta-carotene loaded-lipid polymer hybrid nanoparticles: a preclinical study for breast cancer. Nanomedicine 2017, 12, 1851-1872, https://doi.org/10.2217/nnm-2017-0011.

91. Kumar, A.; Lale, S.V.; Alex, M.A.; Choudhary, V.; Koul, V. Folic acid and trastuzumab conjugated redox responsive random multiblock copolymeric nanocarriers for breast cancer therapy: In-vitro and in-vivo studies. Colloids Surf. B Biointerfaces 2017, 149, 369-378, https://doi.org/10.1016/j.colsurfb.2016.10.044.

92. Massadeh, S.; Omer, M.E.; Alterawi, A.; Ali, R.; Alanazi, F.H.; Almutairi, F.; Almalik, A. Optimized Polyethylene Glycolylated Polymer-Lipid Hybrid Nanoparticles as a Potential Breast Cancer Treatment. Pharmaceutics 2020, 12, https://doi.org/10.3390/pharmaceutics12070666.

93. Zhang, X.; Yang, Y.; Liang, X.; Zeng, X.; Liu, Z.; Tao, W.; Mei, L.Enhancing therapeutic effects of docetaxel-loaded dendritic copolymer nanoparticles by co-treatment with autophagy inhibitor on breast cancer. Theranostics 2014, 4, https://dx.doi.org/10.7150\%2Fthno.9933.

94. Youm, I.; Yang, X.; Murowchick, J.B.; Youan, B.B.C. Encapsulation of docetaxel in oily core polyester nanocapsules intended for breast cancer therapy. Nanoscale Res. Lett. 2011, 6, https://doi.org/10.1186/1556276X-6-630.

95. Anzar, N.; Mirza, M.A.; Anwer, K.; Khuroo, T.; Alshetaili, A.S.; Alshahrani, S.M.; Iqbal, Z. Preparation, evaluation and pharmacokinetic studies of spray dried PLGA polymeric submicron particles of simvastatin for the effective treatment of breast cancer. J. Mol. Liquids 2018, 249, 609-616, https://doi.org/10.1016/j.molliq.2017.11.081.

96. Kommareddy, S.; Amiji, M. Biodistribution and pharmacokinetic analysis of long-circulating thiolated gelatin nanoparticles following systemic administration in breast cancer-bearing mice. J. Pharm. Sci. 2007, 96, 397-407, https://doi.org/10.1002/jps.20813.

97. Huo, Z.J.; Wang, S.J.; Wang, Z.Q.; Zuo, W.S.; Liu, P.; Pang, B.; Liu, K. Novel nanosystem to enhance the antitumor activity of lapatinib in breast cancer treatment: therapeutic efficacy evaluation. Cancer Sci. 2015, 106, 1429-1437, https://doi.org/10.1111/cas.12737.

98. Das, M.; Dilnawaz, F.; Sahoo, S.K. Targeted nutlin-3a loaded nanoparticles inhibiting p53-MDM2 interaction: novel strategy for breast cancer therapy. Nanomedicine 2011, 6, 489-507, https://doi.org/10.2217/nnm.10.102.

99. Desale, S.S.; Raja, S.M.; Kim, J.O.; Mohapatra, B.; Soni, K.S.; Luan, H.; Band, V. Polypeptide-based nanogels co-encapsulating a synergistic combination of doxorubicin with 17-AAG show potent anti-tumor activity in ErbB2-driven breast cancer models. J. Control. Release 2015, 208, 59-66, https://doi.org/10.1016/j.jconrel.2015.02.001.

100. Ahmad, R.; Kaus, N.H.M.; Hamid, S. Synthesis and characterization of PLGA-PEG thymoquinone nanoparticles and its cytotoxicity effects in tamoxifen-resistant breast cancer cells. Adv. Exp. Med. Biol. 2018, 1-18, https://doi.org/10.1007/5584_2018_302. 
101. Wong, H.L.; Bendayan, R.; Rauth, A.M.; Wu, X.Y. Simultaneous delivery of doxorubicin and GG918 (Elacridar) by new polymer-lipid hybrid nanoparticles (PLN) for enhanced treatment of multidrug-resistant breast cancer. J. Control. Release 2006, 116, 275-284, https://doi.org/10.1016/j.jconrel.2006.09.007.

102. Zhou, W.; Zhou, Y.; Wu, J.; Liu, Z.; Zhao, H.; Liu, J.; Ding, J. Aptamer-nanoparticle bioconjugates enhance intracellular delivery of vinorelbine to breast cancer cells. J. Drug Target. 2014, 22, 57-66, https://doi.org/10.3109/1061186X.2013.839683.

103. He, X.; Li, L.; Su, H.; Zhou, D.; Song, H.; Wang, L.; Jiang, X. Poly (ethylene glycol)-block-poly ( $\varepsilon^{-}$ caprolactone)-and phospholipid-based stealth nanoparticles with enhanced therapeutic efficacy on murine breast cancer by improved intracellular drug delivery. Int. J. Nanomedicine 2015, 10, https://dx.doi.org/10.2147\%2FIJN.S75186.

104. Jadon, R.S.; Sharma, M. Docetaxel-loaded lipid-polymer hybrid nanoparticles for breast cancer therapeutics. J. Drug Deliv. Sci. Technol. 2019, 51, 475-484, https://doi.org/10.1016/j.jddst.2019.03.039.

105. Tahir, N.; Madni, A.; Correia, A.; Rehman, M.; Balasubramanian, V.; Khan, M.M.; Santos, H.A. Lipidpolymer hybrid nanoparticles for controlled delivery of hydrophilic and lipophilic doxorubicin for breast cancer therapy. Int. J. Nanomedicine 2019, 14, https://dx.doi.org/10.2147\%2FIJN.S209325.

106. Tan, L.; Peng, J.; Zhao, Q.; Zhang, L.; Tang, X.; Chen, L.; Qian, Z. A novel MPEG-PDLLA-PLL copolymer for docetaxel delivery in breast cancer therapy. Theranostics 2017, 7, https://dx.doi.org/10.7150\%2Fthno.19680.

107. Verderio, P.; Bonetti, P.; Colombo, M.; Pandolfi, L.;Prosperi, D. Intracellular drug release from curcuminloaded PLGA nanoparticles induces G2/M block in breast cancer cells. Biomacromolecules 2013, 14, 672682, https://doi.org/10.1021/bm3017324.

108. Esfandiarpour-Boroujeni, S.; Bagheri-Khoulenjani, S.; Mirzadeh, H.; Amanpour, S. Fabrication and study of curcumin loaded nanoparticles based on folate-chitosan for breast cancer therapy application. Carbohydr. Polym. 2017, 168, 14-21, https://doi.org/10.1016/j.carbpol.2017.03.031.

109. Niza, E.; Nieto-Jiménez, C.; Noblejas-López, M.D.M.; Bravo, I.; Castro-Osma, J.A.; De La Cruz-Martínez, F.; Hermida-Merino, D. Poly (cyclohexene phthalate) nanoparticles for controlled dasatinib delivery in breast cancer therapy. Nanomaterials 2019, 9, https://doi.org/10.3390/nano9091208.

110. Kurzrock, R.; Li, L.; Mehta, K.; Aggarwal, B.B. Liposomal curcumin for treatment of cancer. WO/2004/080396. 2004.

111. Leuschner, C.; Kumar, C.S.S.R.; Hansel, W.; Hormes, J. In vivo imaging and therapy with magnetic nanoparticle conjugates. WO/2007/021621. 2007.

112. Leuschner, C.; Kumar, C.S.S.R.; Hansel, W.; Hormes, J. In-vivo imaging and therapy with magnetic nanoparticle conjugates. EP1912564. 2008.

113. Desai, N.P.; Soon, S.P. Breast cancer therapy based on hormone receptor status with nanoparticles comprising taxane. WO/2008/076373. 2008.

114. Desai, N.P.; Soon, S.P. Breast cancer therapy based on hormone receptors status with nanoparticles comprising taxane. CA2672618. 2008.

115. Desai, N.P.; Soon, S.P. Breast cancer therapy based on hormone receptor status with nanoparticles comprising taxane. EP2117520. 2009.

116. Desai, N.P.; Soon, S.P. Breast cancer therapy based on hormone receptors status with nanoparticles comprising taxane. US20100048499. 2010.

117. Leuschner, C.; Kumar, C.S.S.R.; Hansel, W.; Hormes, J. In-Vivo Imaging and Therapy with Magnetic Nanoparticle Conjugates. US20090169478. 2009.

118. Zhang, Z.; Guo, X.; Zhang Z.; Hu, H.; Mei, Q.; Xing, Y. Hydrogel nanoparticles used as injectable subcutaneous implant agent. CN101953775. 2011.

119. Oyelere, A.K.; El-sayed, M.A.A.; Dreaden, E.C. Targeted cellular delivery of nanoparticles. US20110077581. 2010.

120. Adair, J.H.; Kester, M.; Smith, J.P.; Altinoglu, E.I.; Barth, B.M.; Kaiser, J.M.; Matters, G.L.; McGovern, C.; Morgan, T.T.; Sharma, R.; Shanmugavelandy, S.S. Bioconjugation of calcium phosphosilicate nanoparticles for selective targeting of cells in vivo. WO/2011/057216. 2011.

121. Velayudhan, S. All field simultaneous radiation therapy. US08173983. 2012.

122. Wu, P.; Cai, C.; Zhang, H. Specific detection method of human breast cancer cells MCF-7 based on surfaceenhanced Raman spectroscopy. CN102608102. 2012.

123. Prados Salazar, J.C.; Aránega Jiménez, A.; Melguizo Alonso, C.; Ortiz Quesada, R.; Ruíz Martínez, A.; Gallardo Lara, V.; Arias Mediano, J.L.; Rama Ballesteros, A.R.; Delgado Pérez, J.R.; Luque Caro, R..; González Flores, E. Development and use of polymer nanoparticles comprising Poly[Epiloncaprolactone and Doxorubicin. WO/2012/104461. 2012.

124. Castillo Rodriguez, R.A.; Escobedo Sanchez, M.D.L.; Martinez F.D. NTS-Polyplex nanoparticles system for gene therapy of cancer. WO/2012/107908. 2012.

125. Mary, A.P.K. Nano-Gelatin Encapsulated composition of Glutathione reductase and Lycopene. IN3233/CHE/2012. 2012. 
126. Chen, Y.; Zhou, L.; Zhang, Z.; Yuan, L. Tripterine nanostructure lipid carrier modified by lentiviral vector and appliance for preparing and treating prostatic cancer, lung cancer and breast cancer drug. CN102670510. 2012.

127. Ray, P.C. Popcorn Shape Gold Nanoparticle for Targeted Diagnosis, Photothermal Treatment and In-Situ Monitoring Therapy Response for cancer and Multiple Drug Resistance Bacteria. US20120302940. 2012.

128. Dhar, S.; Choi, J.; Marrache, S. Immune-stimulating photoactive hybrid nanoparticles. WO/2013/012628. 2013.

129. Desai, N.P.; Soon, S.P. Breast cancer therapy based on hormone receptor status with nanoparticles comprising taxane. US2 0130280337. 2013.

130. Castillo Rodriguez, R.A.; Escobedo Sanchez, M.D.L.; Martinez, F.D. NTS-polyplex nanaoparticles system for gene therapy of cancer. CN103458931. 2013.

131. Desai, N.P.; Soon, S.P. Methods of treating breast cancer using nanoparticles comprising taxane based on hormone receptor status. JP2014080443. 2014.

132. Heller, D.A.; Wallas, J.; Levi, Y.; Pratt, G.W.; Anderson, D.G.; Langer R. Modular polymer hydrogel nanoparticle and methods of their manufacture. US20140220346. 2014.

133. Dhar, S.; Choi, J.; Marrache, S. Immune-stimulating photoactive hybrid nanoparticles. US20140220143. 2014.

134. Sim, S.J.; Ma, X. Method for detecting single mismatches in DNA hybridization reaction using gold nanoparticles. KR1020140097679. 2014.

135. Li, W.; Gu, S.; Sun, Y. Targeting modified gold nanorod targeted drug delivery compound and application of delivery compound to anti-tumor photothermal therapy. CN104368000. 2015.

136. Zhou, X.; Jiang, G.; Shen, X.; Xu, L. Method used for detecting content of adenosine triphosadenine in breast cancer cell with colorimetric biosensor and constructed based on gold nanoparticles. CN105717103. 2016.

137. Lin, J.; Huang, Z.; Yang, L.; Fan, L.; Zeng, Y. Aptamer-modified gold nanoparticle-graphene composite material and preparation method and application thereof. CN105879027. 2016.

138. Koshelev, O.K.; Lai, P.; Chen, N.G.; Hsiao, M.; Chen, C.H. Nanoparticle-assisted ultrasound for breast cancer therapy. US20150328485. 2016.

139. Guan, Y.; Zhang, L. Fabrication method and application of cellulose membrane of a drug loading breast cancer- targeting magnetic nanoparticles. CN106310256. 2017.

140. Bhattacharya, S. A process of preparing efficient herbal nanoparticles of solasodine for breast cancer. IN781/KOL/2015. 2017.

141. Yu, X.; Guo, F. Methods and compositions for assaying blood levels of legumain. US20170089909. 2017.

142. Yu, X.; Guo, F. Methods and compositions for assaying blood levels of legumain. US20170089910. 2017.

143. Guan, Y.; Du, S.; Zhang, L. Preparation method and application of photosensitive magnetic nanoparticle system capable of inhibiting growth of breast cancer cells. CN106668871. 2017.

144. Pierce, D.; Carleton, M. Combination therapy comprising nanoparticles of a taxane and albumin with abt263 in methods for treating cancer. US20170202782. 2017.

145. Mohs, A.; Steve, K. Hyaluronic Acid-Based Nanoparticles as Biosensors for Imaging-Guided Surgery and Drug Delivery Vehicles and Methods Associated Therewith. US20170202982. 2017.

146. Bupesh, G.; Vijaykumar, T.S.; Elizabeth, A.A.; Shanthi, B.; Subramanian, P. An anticancer compound. US201741022701. 2017.

147. Wang, C.; Guan, M.; Shu, C. Application of N-fullerene amino acid derivative nanoparticles to preparation of medicine for treating tumor under illumination condition and medicine. CN107551272. 2018.

148. Wei, D. Nanoparticle silica gel capable of being used as injectable subcutaneous implant. CN107595768. 2018.

149. Gouda, H.; Takahashi, M.; Takanashi, K.; Okada, H.; Ozaki, Y.; Yoshihara Y.; Nakano, Y.; Gonda, K.; Ohuchi, N.; Watanabe, M.; Masuda, N.; Tada, H.; Miyashita, M. Test support method for supporting prediction of pathological complete response (pcr) using fluorescent nanoparticles. EP3321682. 2018.

150. Zhang, Y.; Zhu, X.; Ma, J.; Wu, T.; Wang, Y.; Zhao, J.; Chen, L.; Lu, W.; Zhai, X.; Zhang, J.; Chen, G.; Cao, Y.; Sun, P.; Lio, L.; Sheng, H.; Zhou, Y. Electrochemical detection method for stem cells. CN108088882. 2018.

151. Shen, B.; Xu, X.; Zuo, X. Polypeptide for promoting apoptosis of breast cancer cells by targeted uptake of siRNA. CN108117585. 2018.

152. Zhang, X.; Guo, P. Multifunctional RNA nanoparticles and Methods for treating cancer and Therapeutic Resistant Cancer. WO/2018/106992. 2018.

153. Shaoquin, G.; Wei, X.; Yuyuan, W.; Fabao, L. Therapeutic cationic peptides and unimolecular nanoparticles for efficient delivery thereof. US20180235897. 2018.

154. Adhikary, A.; Bhattacharya, S.; Ghosh, A. Hyaluronic Acid-Decorated Thymoquinone-Loaded Pluronic ${ }^{\circledR}$ P123-F127 Mixed Polymer nanoparticles as Targeted Therapy against Triple Negative Breast cancer. IN201831021395. 2018.

155. Liu, Z.; Tao, Z.; Zhang, Q.; Wan, S.; Zhang, F. Specific targeted breast cancer cell mesoporous silicon nanometer drug loading system and preparation method thereof. CN108671236. 2018. 
156. Vijayalakshmi, C.; Srinivasan, R.; Venkatesan, S.S. Keratin based Nanobiocomposite for Cancer Cell Targeting and Imaging. IN201741017595. 2018.

157. Xue, P.; Yang, R.; Kang, Y.; Zhang, L. Preparing of polyethyleneimine modified photosensitizer-carried Prussia blue magnetic nanoparticles. CN108904803. 2018.

158. Xiao, B.; Huang, Y. Silk fibroin-based nanodrug for targeted combined chemotherapy of breast cancer, and preparation method thereof. CN108926567. 2018.

159. Shi, B.; Ren, F.; Du, Q.; Zheng, M. Gold nanoparticles and synthetic method thereof. CN109047791. 2018.

160. Yu, X.; Guo, F. Methods and Compositions for assaying blood levels of Legumain. 20190011451. 2019.

161. Deng, L.; Sun, Y.; Wang, Z.; Liu, M. HER2-targeted phase-change PLGA nanoparticle, application and preparation method thereof. CN109172829. 2019.

162. Durfee, P.N.; Brinker, C.J.; Lin, Y.S.; Leong, H. Osteotropic Nanoparticles for Prevention or Treatment of Bone Metastases. US20190022235. 2019.

163. Adhikary, A.; Ahir, M.; Ghosh, A. Hyaluronic Acid appended PEG-PLGA coated quarternized mesoporous Silica nanoparticles for delivery of Mirnas in TNBC. IN201931006560. 2019.

164. Liu, W.; Wu, Y. Near-infrared responsive nano-composite supramolecular hydrogel and preparation method thereof. CN109503862. 2019.

165. Liu, W.; Wu, Y. Application of nanogold-based composite supermolecular hydrogel as biomedical material. CN109504648. 2019.

166. Rajarathinam, M. Method and System for synthesizing "Green” biocompatible Organic-Inorganic Hybrid Electrospun Nanofibers for potential Biomedical applications. IN201741034940. 2019.

167. Vijayakumar, S. Development of Engineered Gold Nanoparticles for High Contrast Imaging of Tumor in XRay Photography And Pharmacokinetic Studies in Vivo.IN201741038811. 2019.

168. Vardhan, H.; Mishra, B. Improved Pharmaceutical Compositions of Docetaxel Polymeric Nanoparticles and Preparations Thereof. IN201711038532. 2019.

169. Jiang, C.; Zhang, Y. Macrophages membrane coated breast cancer targeted nanoparticles and preparation method thereof. CN109953972. 2019.

170. Jiang, L.; Zhou, Y.; Chen, D.; Xue, G.; Yuan, C.; Huang, C. Preparation method of quercetin nanoparticles and application of quercetin nanoparticles in preparing drug for resisting breast cancer. CN109999002. 2019.

171. Tao, X.; Wen, S.; Wu, D.; Chen, Y.; Deng, X.; Hou, D.; Zhang, Q.; Quin, G. Pullulan nanoparticles with cosupported lovastatin and doxorubicin and preparation method thereof. CN110201181. 2019.

172. Li, X.; Liu, X.; Ding, L.; Zhang, S. Preparation and application of nanoparticle doped RNA hydrogel for targeted triple negative breast cancer. CN110327464. 2019.

173. Shen, P.; Cui, L.; Yang, C.; Liu, W. Novel RGD-chitosan oligosaccharide silicon oxide/BCSG1-siRNA nanoparticle breast cancer targeted therapy method. CN110339372. 2019.

174. Kim, A.J.; Woodworth, G.F.; Jeffrey, A.W.; Wadajkar, A. Decreased Adhesivity Receptor-Targeted Nanoparticles for Fn14-Positive Tumors. US20190328677. 2019.

175. Tang, B.; Li, Y.; Li, N.; Pan, W. Preparation and application of nano-immunological preparation based on porous calcium carbonate. CN110420335. 2019.

176. Zhang, X.; Guo, P. Multifunctional RNA Nanoparticles and Methods for Treating Cancer and Therapeutic Resistant Cancer. US20190351067. 2019.

177. Wu, Y.; Hai, L.; Guan, M.; Guo, L.; Peng, Y.; Pu, Y. Fructose and RGD peptide co-modified dual-targeting triple-negative breast cancer lipid material.CN110522923. 2019.

178. Vijayakumar, S. Green Synthesis of Gold nanoparticles Using Fruit Extracts - Bael Fruit, Eugenia Jambolana And Sours. IN201741038806. 2019.

179. Deng, C.; Chen, W. Fluorescent aptamer probe based on Prussian blue nanoparticles as well as preparation method and application of fluorescent aptamer probe. CN110669499. 2020.

180. Mehtap, K.; Gökhan, K.; Engin, U. Lipid Nanoparticles Loaded with Ceranib-2 as Anticancer Agent. WO/2020/018049. 2020.

181. Harrison, R.G.; Virani, N.A. Gold Nanoparticle-Ligand Conjugates and Methods of Use. WO/2020/041267. 2020.

182. Hai, L.; Wu, Y.; Guo, L.; Pu, Y.; Peng, Y.; Li, R. Preparation and application of breast cancer targeted liposome modified by biotin and glucose. CN110840844. 2020.

183. Huang, M.; Guo, N.; Li, L.; Yuan, C.; Jiang, L. Preparation method of CPZ-coupled MS2 protein nanoparticles and application thereof in breast cancer resistance. CN110841073. 2020.

184. Wen, L.; Zhang, Y.; Sha, R.; Zeng, J.; Zhang, L. Application of copper-palladium alloy nanoparticles and autophagy inhibitors in preparing tumor killing drugs or kits based on photothermal effects. CN110893237. 2020.

185. Wu, Y.; Hai, L.; Guo, L.; Yue, Q.; Pu, Y.; Peng, Y. Preparation and application of multi-branch biotin modified breast cancer targeted liposomes. CN110917139. 2020.

186. Chen, J.; Xu, M. Calcium phosphate-lipid nano-drug co-delivery system consisting of low molecular weight heparin and prodrug of natural drug. CN110960507. 2020.

187. Sun, J.; He, Z.; Ye, H.; Wang, K. Adriamycin-indocyanine green bionic nanoparticles and application thereof. CN111000822. 2020. 
188. Sahin, F.; Tasli, P.N.; Kirbas, O.K.; Hayal, T.B.; Bozkurt, B.T.; Bulbul, B.T.; Bulbul, B.; Beyaz, S. Use of Mutant P53 Gene Targeted Lead Borate nanoparticles in cancer Treatment and Production Method of These nanoparticles. WO/2020/086014. 2020.

189. Lu, X.; He, X.; Xu, J. Ph-Activated nanoparticles. WO/2020/092602. 2020.

190. Manimaran, D.; Elangovan, N.; Jagatheeh, K. A Formulation and Evaluation of The Peptide Hif9 Loaded chitosan Nanoparticles. IN202041013943. 2020.

191. VanderSpek, L.L.; Targeted nanoparticles for Glioblastoma Theranostics. US20200206144. 2020.

192. Gong, S.; Xu, W.; Wang, Y.; Liu, F. Therapeutic Cationic Peptides and Unimolecular nanoparticles for Efficient Delivery Thereof. US20200276130. 2020.

193. https://clinicaltrials.gov/ct2/show/NCT00915369 (accessed on 20th October 2020).

194. https://clinicaltrials.gov/ct2/show/NCT00436709 (accessed on 20th October 2020).

195. https://clinicaltrials.gov/ct2/show/NCT00609791 (accessed on 20th October 2020).

196. https://clinicaltrials.gov/ct2/show/NCT04482803 (accessed on 20th October 2020).

197. https://clinicaltrials.gov/ct2/show/NCT00629499 (accessed on 20th October 2020).

198. https://clinicaltrials.gov/ct2/show/NCT04138342 (accessed on 20th October 2020).

199. https://clinicaltrials.gov/ct2/show/NCT03505528 (accessed on 20th October 2020).

200. https://clinicaltrials.gov/ct2/show/NCT00616967 (accessed on 20th October 2020).

201. https://clinicaltrials.gov/ct2/show/NCT00407888 (accessed on 20th October 2020).

202. https://clinicaltrials.gov/ct2/show/NCT00733408 (accessed on 20th October 2020).

203. https://clinicaltrials.gov/ct2/show/NCT03719326 (accessed on 20th October 2020).

204. https://clinicaltrials.gov/ct2/show/NCT00618657 (accessed on 20th October 2020).

205. https://clinicaltrials.gov/ct2/show/NCT02106598 (accessed on 20th October 2020).

206. https://clinicaltrials.gov/ct2/show/NCT01746225 (accessed on 20th October 2020).

207. https://clinicaltrials.gov/ct2/show/NCT00709761 (accessed on 20th October 2020).

208. https://clinicaltrials.gov/ct2/show/NCT03289819 (accessed on 20th October 2020).

209. https://clinicaltrials.gov/ct2/show/NCT02646319 (accessed on 20th October 2020).

210. https://clinicaltrials.gov/ct2/show/NCT04216472 (accessed on 20th October 2020).

211. https://clinicaltrials.gov/ct2/show/NCT04249167 (accessed on 20th October 2020).

212. https://clinicaltrials.gov/ct2/show/NCT03606967 (accessed on 20th October 2020).

213. https://clinicaltrials.gov/ct2/show/NCT02762981 (accessed on 20th October 2020). 